\title{
The urban rent
}

in the multicultural city: retail shops,

migrants and

urban decline

in the historic centre

of Palermo

Grazia Napoli*, Giulia Bonafede**

keywords: rent; retail shops; migrants; multicultural city; real estate market; historic centre.

\begin{abstract}
Changes in consumer shopping behavior and in retail spaces, such as shopping malls, department stores and e-commerce, have modified localization models of traditional retail shops, also affecting urban fabric and spatial distribution of urban rent. Even city centers have undergone significant transformations or even decline, especially if local economic system and real estate market are weak and recessionary. A significant amount of commercial properties may have long vacancy due to excess supply, since many traditional shops close their business because they are no longer competitive and, moreover, there is no immediate takeover by new tenants.

The decline of central urban areas depends on the interaction of multiple economic, social and cultural

factors, but it can be countered by urban policies oriented not only to physical redevelopment of urban fabric, but also to social cohesion and multiculturalism. Migrants bearers of varied cultural values, coming from different continents and settling permanently in the Italian cities, have rented some of these empty properties by locating retail shops specifically oriented to their own communities or also to the citizens needs. The presence of migrants contributes, indeed, to support the retail real estate demand, to mitigate the minus-valorization of real estate capital and also to contain the revenues contraction. This phenomenon has been analyzed in some streets of the historic centre of Palermo that are traditionally shopping areas and have become the privileged place for locating retail shops managed by immigrants.
\end{abstract}




\section{INTRODUCTION}

As a complex effect of economic globalization process, the spreading of new forms of retail and other services (like shopping mall and, more recently, e-commerce websites) deeply etches on the transformation of cities and urban regions. This occurs both from the perspective of commercial real estate market and urban development, with implications involving residential localizations and multicultural relationships.

Especially in geographic areas marked by a weak economic structure and by housing-market stagnation, new retail modes have caused socio-economic polarization phenomena and have contributed to commercial fabric decline also in urban central areas, as occurred in many Sicilian towns. Particularly in the historic centre of Palermo, this decline has favoured the permeability to localisation of migrants' economic activities that are usually nearby to their housing (Bonafede and Napoli, 2016; Forte et al., 2018).

Although in recent years a greater influx of migrants has interested the intensively cultivated areas of rural Sicily, the metropolitan cities of Palermo, Messina and Catania remain indeed the main poles of attraction for the migration flows because of a major concentration of work opportunity, mostly in jobs of retail and domestic care (Todaro, 2018).

Caused by the same global dynamics, the migration flows actually challenge cities and regions from multiple perspectives, especially from the viewpoint of building new intercultural development models. Amongst other involved social and economical policies, these people transnational flows emphasize many cultural contradictions also in town planning (Sassen, 1996 and 2001; Sandercock, 1998 and 2000), which often interacts with different studies (anthropological, ethnographical, post-colonial and geographical) in order to incisively explore the territories of differences and their rights (Appadurai, 2001; Baroni, 2013; Holston, 1998; Young, 1990; Soja, 2007; Scott, 2011).

Alternatively to proliferation of contacts, public spaces and virtual markets, the choices of immigrants' location in degraded urban areas, where housing and shops are inexpensive, can be considered as opportunities for a kind of urban revitalization that is instead anchored on the multicultural relationships and the city material space.

From this perspective, the research aims at investigating in which terms the presence of migrants helps to sustain commercial real estate demand and contain annuities decrease, by analysing the case of the historic centre of Palermo in a frame of interdependent effects by the proliferation of mega stores or malls in other parts of the city and by the spread of e-commerce in the virtual space.

In addition, the study underlines the multicultural values emerging by the slow building process of public space as a result of social interactions, which are rooted in the urban fabric, in comparison with the closed and predetermined space of the malls.

\section{GLOBAL TRADE AND URBAN SPACE}

The complex relationships among social communities (which differ for income, cultural models, geographical origins), places (centre and centrality, periphery and marginality) and functions (complementary, synergistic and conflicting) are subjected to continue tension between change and persistence where city resilient capabilities allow it to modify itself while maintaining its own identity.

The locational patterns of commercial activities have always been an integral part of the urban structure, from the market-square in the city centre to the shopping malls, which transform urban peripheries or the areas out of town into place dedicated exclusively to consumption.

Emblems of globalized trade, shopping malls were born in US, in the 1920s, and developed in Europe, starting by the 1970s; they have largely spread because of the supply of goods at low prices and initially settled in urban central areas with multilevel buildings (Moccia and Sgobbi, 2013).

At the beginning of new millennium, the new models have evolved into increasingly extensive and complex facilities localized in peripheral areas as nodes of a large scale infrastructural network, serviced by huge parking lots, wide roads and highway junctions.

In addition to main areas dedicated to retail (Gross Leasable Areas), during this evolution, further areas have been added in order to play different functions as leisure and cultural entertainment (mainly kids' play-areas and cinemas), sports (small gyms), meetings (conference rooms), services (bank and post office) and catering (bar, restaurants and fast food areas).

The attempt is to build ex novo a new polarity in peripheral position where there is a concentration of several activities which are usually dislocated in different public spaces of downtown (streets, squares and galleries), while in the malls these latter become privates spaces open to the public fruition for the sole purpose of supporting the consumption activities.

In this kind of globalized spaces, the flattening and homogenising of relational skills (Augé, 2009) have fed a renewed critical reflection on the concept of public space and its contraction in favour of privatization.

The new shopping malls have been defined as "pseudo public spaces" (Giampino et al., 2017) because they compensate the lack of meeting places as an outcome of behaviours and predetermined spatial models rather than being a social "social construct" as it should result from a social interaction process (Crosta, 2000).

They were also called "non-places" since do not interact with the surrounding landscape and urban space and represent one of the forms of "city-world" without history neither identity (Augé, 2009). 
The urban rent in the multicultural city: retail shops, migrants and urban decline in the historic centre of Palermo

The mall indubitably attracts vastly different kinds of people and generations and especially during the weekend can be considered as one of "urban glamour zones" not only in the network of main global cities (Sassen, 1996, 2001), but also in the globalized outskirts. In any case, this sort of attractive and trendy market implies high costs for its maintenance and sometimes has really short life.

In the United States, from some time the phenomenon of dead malls has already appeared and has been studied in order to understand the reasons of their decline and to intervene with sustainable redevelopment projects (Moccia and Sgobbi, 2013).

However, the reconversion interventions of malls (demalling) have been implemented in a paradoxical way: by rebuilding historical settlement models, with their typical functional mix (residence, offices, shops and activities of leisure) of the urban fabric, and by restoring the trade spaces according to persistent modes from centuries, such as the open air markets and shops along the streets. From this perspective, also some extremely large car parking lots have been reconverted in public parks, with remarkable expenditure for restoring the vegetable soil.

In Sicily, the shopping malls spread late compared to other Italian regions and were sometimes overshadowed by suspicion to be a means for recycling the proceeds of dubious economic businesses. (Cannarozzo, 2009; Bazzi, 2012). The malls were indeed built in Sicily during a critical economic phase, when the reduction of public expenditure pushes the municipalities to decline their urban redevelopment policy in favour to a founded strategy on private actors' financing. Especially in Palermo, these big structures have been localized near historic rural villages and Public Housing outskirt neighbourhoods marked by high rates of social hardship (high unemployment, widespread school drop-out and low income levels).

Touted as panacea for renewing areas with social exclusion risks and to compensate the lack of public facilities and services, the three main shopping malls in Palermo ("La Torre" in Borgonuovo district, "Conca d'Oro" in the Zen neighbourhood and "Il Forum" in Brancaccio district), were built since 2006, as variant to urban plans and after other negotiation programs between the municipality and private investors. The latters were involved on the creation of collective interest facilities, which however do not always have been constructed or have proved to be inappropriate for the local inhabitants' needs (Bonafede and Lo Piccolo, 2007; Abbate and Orlando, 2009).

This choice to localize malls in urban peripheries not only eroded large extensions of agricultural land - sometimes featuring cultures of environmental value - interrupting potential ecological continuity and social links among different parts of the city (Bonafede and Schilleci, 2009; Marotta and Schilleci, 2016), but it also caused negative impacts on the "natural" shopping centres that had shaped over time, especially in the historic city centre. The malls localization generated phenomena of disorientation with respect to the surrounding landscape of citrus and to the minute proportions of rural villages. In addition the great dimension of malls has really caused the decline of retail, which was traditionally dislocated in various shops or in open-air markets of the urban fabric and particularly of the historic centre, with controversial consequences regarding the real increase of employees in the trade sector, publicized as one of obtained benefits ${ }^{1}$.

\section{URBAN SPACE AND MIGRANTS}

The undoubtedly negative repercussions on retail mainly happen in the historic centre of Palermo, in conjunction with the ineffectiveness of urban recovery policies that have failed to adequately support the low-income householders and small property owners (Bonafede and Napoli, 2015), by negatively impacting on the maintenance of urban fabrics, their economic values and their vivacity.

The emptying of the tertiary functions of important axes, such as that of via Roma and via Maqueda, as well as the decline of some historical markets (e.g. Vucciria market), have nevertheless offered new opportunities for intercultural relationships. This kind of economic decline has activated in fact slow replacement processes (or filtering phenomena) in the spaces left by residential and commercial activities abandoned by the "Italians", which have facilitated the migrants concentration, coming from different countries, in the historic city centre.

In periods of continuing economic crisis, immigrants have therefore contributed to keeping the buildings of the historic centre in use, to supporting the demand for residential and commercial properties, by attenuating the transformations of the real estate market (Napoli et al., 2016a; Napoli et al., 2017a; Ciuna et al., 2017) and the difficulties in identifying cost-effective alternative uses (Napoli, 2015), resisting sometimes to sporadic and fragmentary gentrification processes (Bonafede and Napoli, 2015).

This resilience of the multicultural city, understood as the ability to respond to urban crises by keeping the system in balance with innovative methods, has been investigated not only in terms of market values of real estate capital, but also with regard to the values attributed to the processes of creation of public space and private space for public use.

The variegated system of shops that migrants offer to their communities and which, at the same time, are addressed to all the citizens are indeed opportunities for aggregation and cultural interaction and contribute to constitute "the

\footnotetext{
1 A study finds that in Palermo, from 2006 to 2012, in the face of an increasing number of new employees of shopping malls, the total number of operators in the trade sector decreases (thesis of U. Pera, a.a. 2013/14, supervisor G. Bonafede).
} 
eyes of the road", ensuring even greater security. Conversely, the numerous reception and training services to support immigrant groups in the historic city centre, such as the Astalli Center and Santa Chiara, become crossroads for solidarity events, reinforcing cultural interactions.

If public space is pre-eminently a relational space (Arendt, 1958) and is a "construct" (Crosta, 2000) that is the outcome of a social interactions construction in time and in urban material space (rather than a pre-packaged product), then the way in which the historic centre of Palermo becomes permeable to residential and commercial activities offered by migrant groups expresses, in our opinion, the beginning of a process of building of multicultural values that are to be safeguarded with suitable policies. The network of interactions, in fact, has already created a public space, where differences recognize and respect each other and a mutual learning process occurs.

\section{RENT AND RETAIL REAL ESTATE}

City is the privileged place of exchange of not only purely material goods but also of monetary, symbolic, cultural, ethical and aesthetic values. The monetary form of the city (Rizzo, 2003) corresponds to the spatial organization of rent and constitutes the translation of urban hierarchies, centrality and polarity into monetary values, according to economies of agglomeration, as well as to different levels of accessibility and potential interaction that characterize each urban area (Camagni, 1992). Given that the supply curve of urban real estate is rigid in the short term because it depends on the provisions of urban planning, prices may change in the medium-long term only if real estate quantity varies due to the drafting of new plans or also projects of urban redevelopment notwithstanding the current plans.

The construction of shopping centers has led to a significant increase in the offer of retail properties in local urban markets where there has been a significant reduction in demand of traditional shops. This contraction subsequently extended to the retail spaces in the same shopping centers is causing long vacancy of leased buildings and strong minus-valorization of many properties for sale.

The spread of global e-commerce, moreover, by moving the purchase of many types of goods from a physical place of the exchange (shop) to an abstract site (website), has caused many traditional shops in financial difficulties to close due to reduction of consumption level. Intensification of economic competition has decreased goods prices and thinned profit margins, and consequently has also negatively affected the affordability of rents (Damesick, 2001).

Retail properties have different levels of income and capital value risks related to multiple factors: type of trading, urban location, size and rank of the city, size of catchment area of potential users, technological characteristics of the building (size, state of preservation, constraints, etc.).

As a countermeasure to this decline and in order to remain economically competitive, some international brands are proposing unique and personalized sensory experiences to attract the consumer into the physical place of the stores and move him away from the impersonal purchase on the websites. In these cases the demand for retail real estate is strengthened even if this trend concerns mainly the "high streets" shopping, that are the urban place in which low-budget or high-end clothing chains (high fashion or high tech) and multibrand stores are concentrated.

Although e-commerce tends to reduce the number of trips to the city center (and to the shopping centers too), some studies have verified that if the city center is perceived as an attractive place both in terms of convenient prices and good accessibility, many citizens (and customers) are encouraged to buy in the center rather than through websites (Weltevreden and von Rietbergen, 2006). This is an encouraging result for urban policies aimed at enhancing historic centres and supporting the location of retail shops.

In recent years, there was in Italy a considerable increase in the Number of Normalized Transactions (NTN) of retail real estate, although trade intensification has not yet triggered systematic increasing prices.

The analysis of the OMI data regarding NTN and average prices (2018 Report on 2017 data) shows a diversified framework, when we compare the national and regional average variations with those relative to some capital cities (Fig. 1). It happens because the resilience degree of the local real estate markets, which are subjected to internal and external instabilities, depends on the peculiar combination of micro and macro economic and micro and macro territorial factors and provides different results.

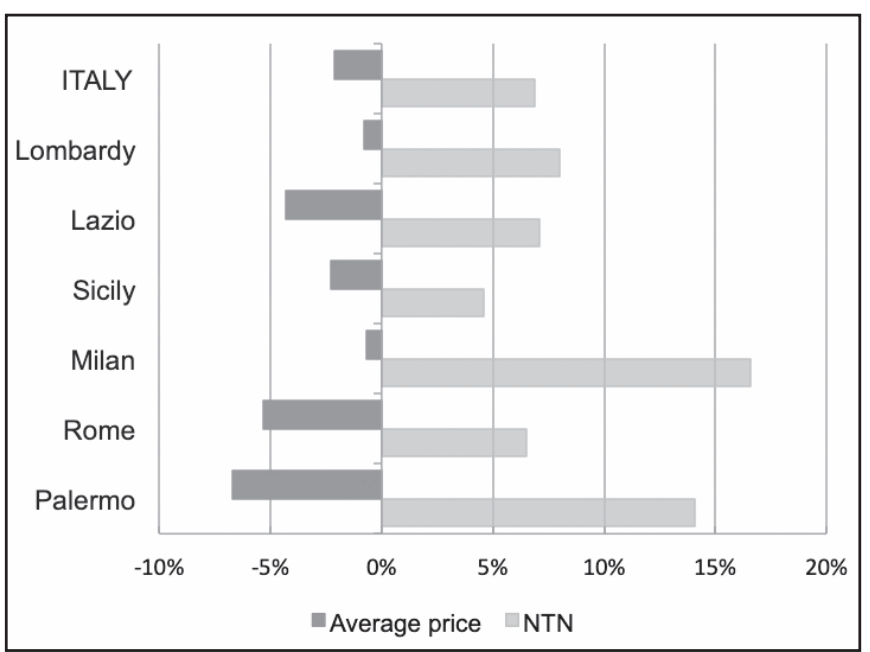

Figure 1 - Variation 2016-2017 of average prices and NTNs (our elaboration on OMI data). 
The urban rent in the multicultural city: retail shops, migrants and urban decline in the historic centre of Palermo

Against a $+6.9 \%$ national average NTN variation, Lombardy and Lazio regions have very similar variation, while the value is much lower for Sicily as it only reaches $+4.6 \%$. Furthermore, there is a large gap between the regional and capital cities data, in fact in Milan and Palermo the NTN has increased by $+16.6 \%$ and $+14.1 \%$ respectively, highlighting the polarizing effect of metropolitan cities on the location of commercial activities compared to any of the regional territory. On the contrary, the NTN variation in Rome is slightly lower than in Lazio.

The analysis of the average prices trend, however, does not always provide similar results. In fact a general minusvalorization of commercial real estate persists and the national average is equal to $-2.1 \%$. By comparison of Lombardy and Lazio prices with the national average value, there are different gaps, as the quotation falls by twice in Lazio $(-4.3 \%)$ and has just a slight decline in Lombardy $(-0.8 \%)$, while it is very close to the national average in Sicily $(-2.3 \%)$.

The falling in prices is even more intense in Rome $(-5.35 \%)$, but it is interesting to note the opposite trends in Milan and Palermo. Despite the strong rising of transactions in both cities, the consequences on prices differ.

In Milan the prices decreased slightly $(-0.7 \%)$, showing that high trade intensity made possible not to increase the bargaining margins and not to lower the price level. In this case the demand is still willing to pay high prices because it expects to obtain a good long-term profitability of the investment, both in terms of rental effortlessness and future plus-valorizations (Giuffrida et al., 2017; Napoli et al., 2017b). In Palermo, on the other hand, there is a further substantial reduction in prices $(-6.7 \%)$ that is indicative of an urban market where the excess supply and the low liquidity of the retail properties result in transactions with a high loss of value and long waiting times for finding a buyer.

The NTN and average prices data are useful to know the real estate market trends, even if the monetary form (prices and incomes) of commercial locations assumes specific and always different connotations in each urban fabric.

On the urban scale, "high street" is a singular market segment that often anticipates and amplifies global or national real estate market trends, which may be even opposite to those that happen in the rest of the city.

Figure 2 shows the minimum and maximum annual rents of some retail properties located in high streets in Milan, Rome and Palermo.

The highest unit rental values are in via Monte Napoleone (with a peak of 9800 euros/sq.m./year) and via della Spiga in Milan, and also in via dei Condotti in Rome $(8000$ euros/sq.m./year), that are all places mainly oriented to foreign tourists shopping and where the symbolic value of Italian luxury and design, as well as of major international brands, is at its maximum.

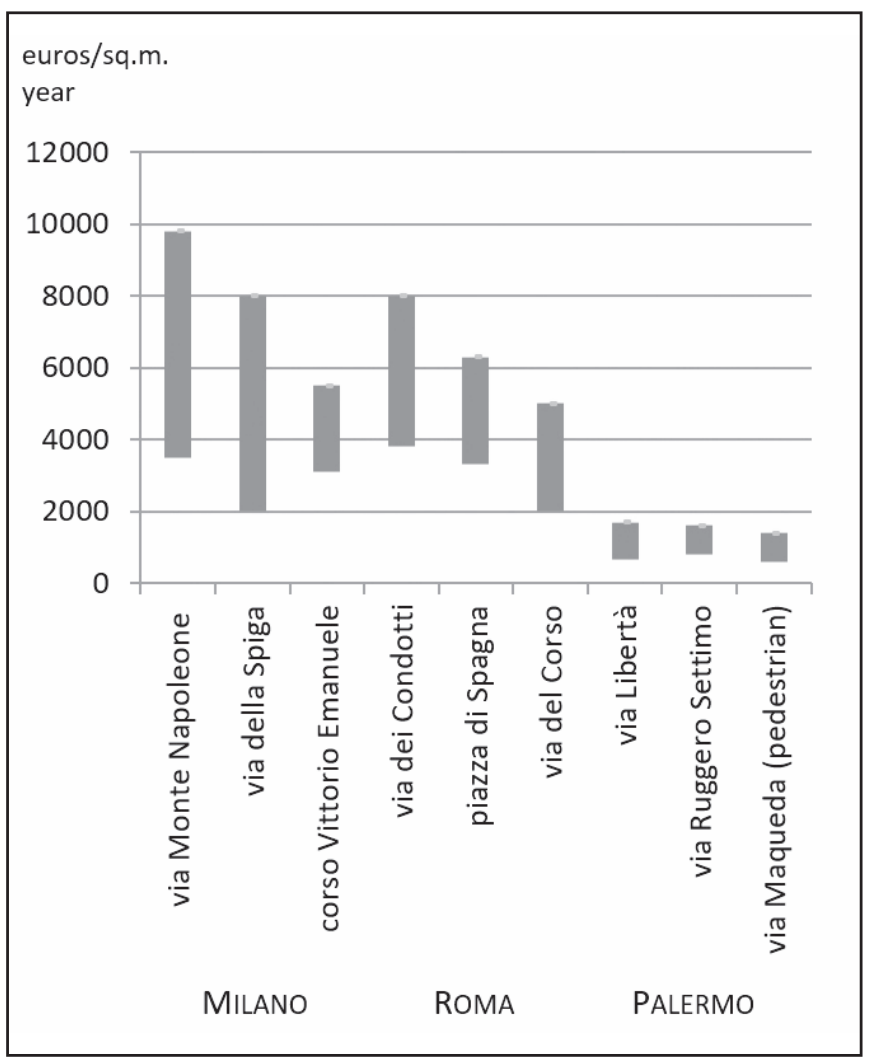

Figure 2 - Lease values in some high streets in Milan, Rome and Palermo (based on 2016 data, World Capital - Real Estate Group).

The most important high street of Palermo is composed of via Maqueda which is a sixteenth-century street in the historic centre, via Ruggero Settimo that crosses the eighteenth-century urban settlement, and via Libertà that leads to the upper class and noblesse districts that were build between the end of the 1800s and the first decades of the 1900s.

The annual lease of retail real estate in this high street (which, however, includes only the section of via Maqueda between piazza Verdi and piazza Vigliena) is far lower than in Milan and Rome and fluctuates between 1700 and 580 euros/sq.m.

The analysis of vacancy times in the same cities provides differentiated results (Fig. 3).

The vacancy time is equal to 8-6 months even in the most popular high street in Milan, probably due to the relatively small number of commercial business able to afford high localization costs, but, sometimes, there may be no vacancy with the immediate replacement of the tenant. Similarly, the vacancy time may vary from 1 to 6 months for properties in via Libertà in Palermo.

Nevertheless the same maximum time vacancy, which is 8 months, differences between via Maqueda and via Monte Napoleone because of the huge gap between the corresponding prices of retail property that denotes the weakness of demand and of social and economic system 


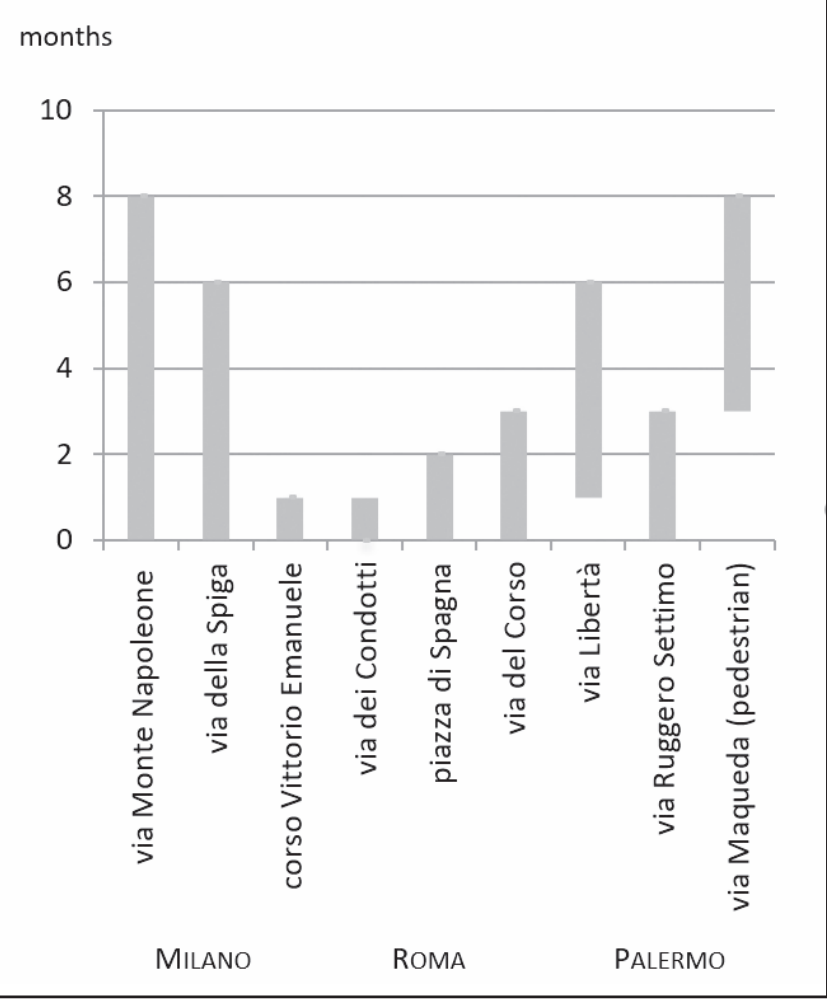

Figure 3 - Time vacancy in some high streets in Milan, Rome and Palermo (based on 2016 data, World Capital - Real Estate Group).

of Palermo. Indeed, despite the presence of a valuable historic and architectural heritage and a great tourist flow, the high streets of the historic centre of Palermo suffer from the competition of the three urban shopping mall and global e-commerce website, that are all factors that contributed to raising future risks on income and market value of retail real estate.

\section{THE CASE STUDY: CITY, IMMIGRANTS AND RETAIL IN PALERMO (ITALY)}

Palermo is a multicultural city in which, in 2011, 28,226 foreigners lived, equal to $4.1 \%$ of the total population (696.562 inhabitants) (Inter-institutional Observatory data). Immigrants were predominantly localized in the Tribunali - Castellammare and Palazzo Reale-Monte di Pietà (forming the historic centre) and Politeama central districts, or in Oreto, Zisa, and Noce semi-central districts (Fig. 4).

The density of immigrants is particularly high in the historic centre where $23.4 \%$ of the 6.488 residents are foreigners (Fig. 5) and moreover there are more than 80 nationalities, although the most numerous communities are those from Bangladesh, Sri Lanka, China, Tunisia, Ghana, Mauritius and Romania (Fig. 6).

The choice of immigrant communities to live in the historic centre has produced significant social and

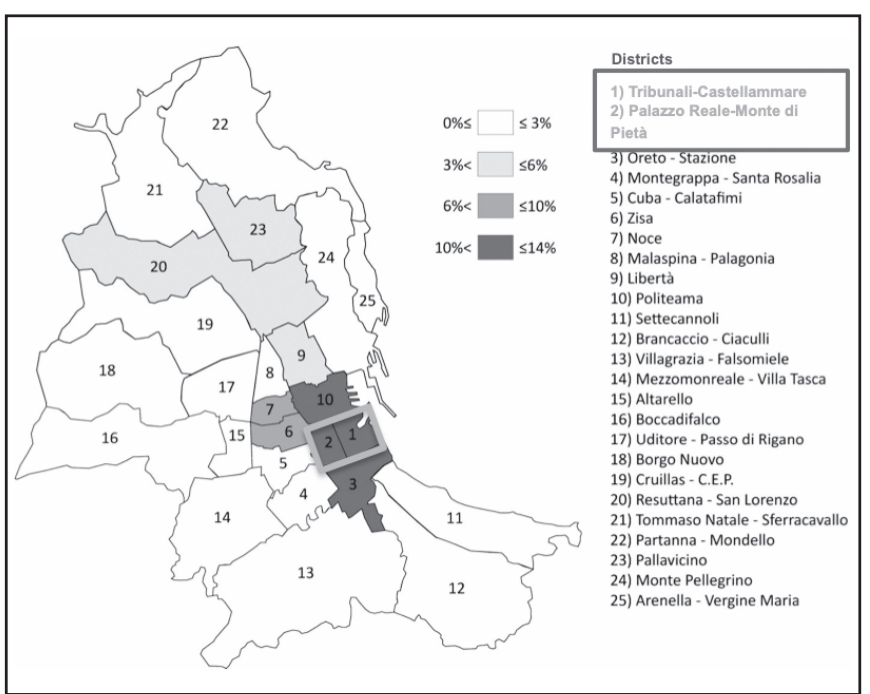

Figure 4 - Localization of immigrants in the neighborhoods of Palermo (2011).

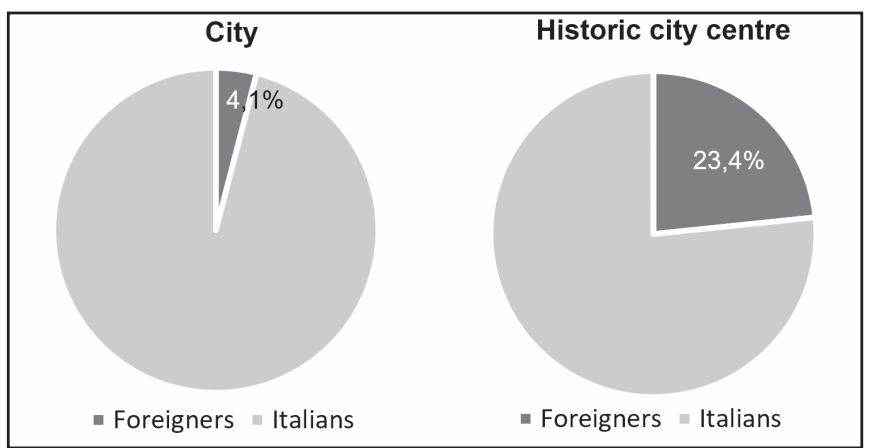

Figure 5 - Foreigner and resident population in Palermo and in the historic centre (2011).

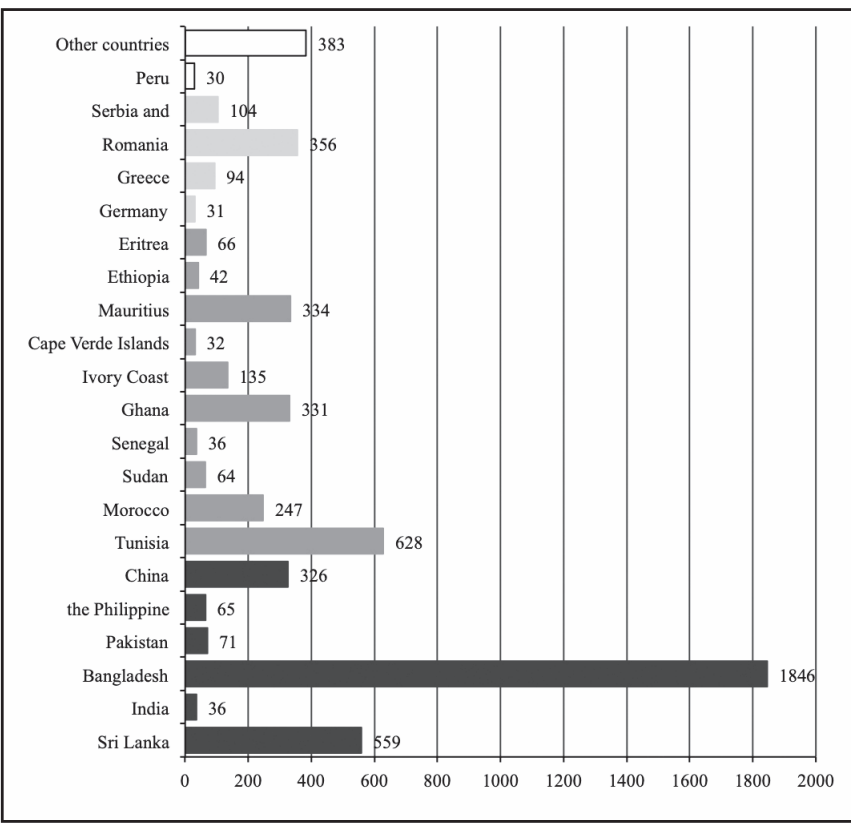

Figure 6 - Immigrants by country, historic centre of Palermo (source: Bonafede and Napoli, 2015, based on 2011 data). 
The urban rent in the multicultural city: retail shops, migrants and urban decline in the historic centre of Palermo

economic consequences also on the local real estate market.

Such an amount of immigrants means, above all, the use of a considerable share of residential real estate, even if immigrants live mainly in low-quality or overcrowding buildings due to their low income-threshold (Napoli et al., 2016b; Napoli, 2017) and furthermore are exposed to the moving risk when gentrification processes are activated, in the same ways as other low-income "indigenous" social groups.

Public space use has been also modified due to the internal and external interactions with foreign communities, both in terms of habits and time of use, and of types of users, forming new hierarchies of inclusive or exclusive urban spaces (Bonafede and Napoli, 2015).

Another direct consequence concerns the use of retail properties and the management of retail shops and services, which strengthens the presence of immigrants in the neighborhood. These economic businesses managed by immigrants may be oriented to the needs of their own community or entire citizenship, as well as of the tourists who visit the historic centre.

In the current situation of high supply of retail properties, immigrants have an active role in the local real estate market and ensure a continuous income flow to landlords.

To verify the role of immigrants in this specific market

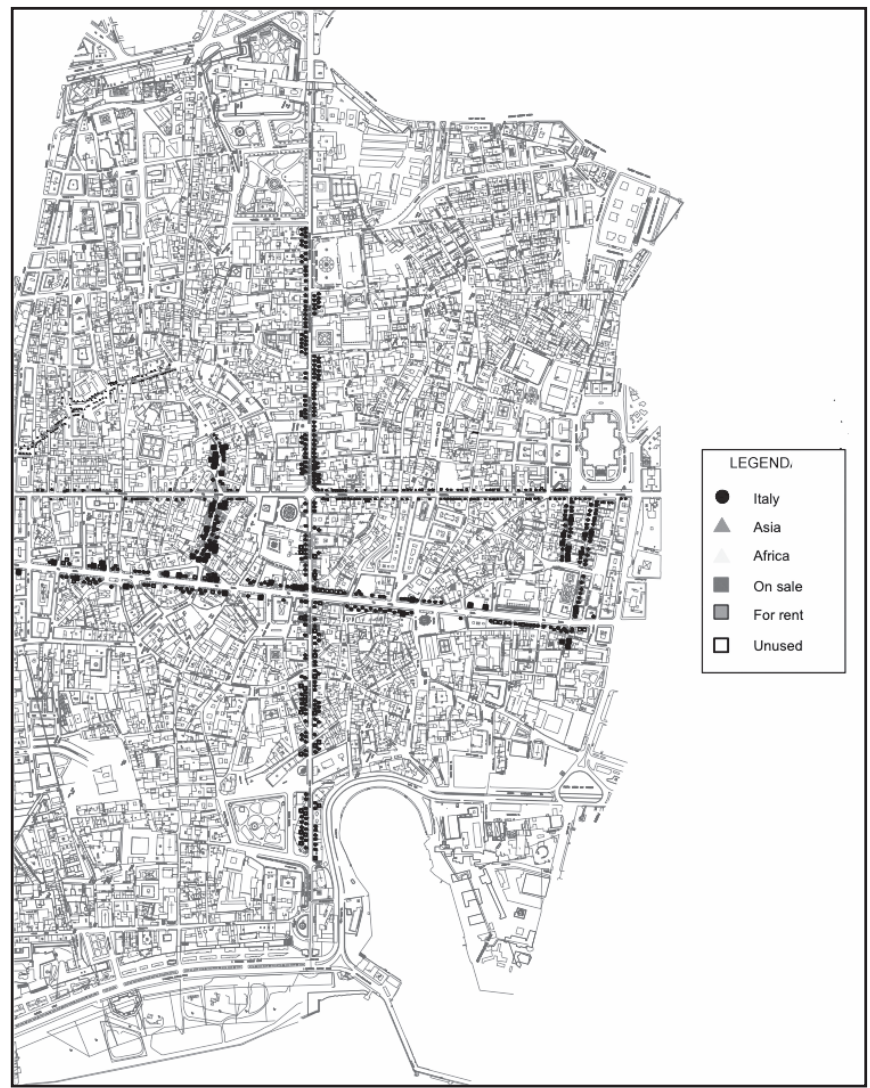

Figure 7 - Location of retail shops of the case study (historic centre of Palermo). segment, a survey has been conducted focusing on the retail shops that are located in the following shopping streets of the historic centre (Fig. 7):

- corso Vittorio Emanuele or Cassaro (al-Qasr), which was the main street of the city until the 16th century;

- via Maqueda, built between the end of the 1500s and the beginning of the 1600s, that crosses Corso Vittorio Emanuele and divides the ancient city into four districts. It has imparted the direction of new urban districts and is subsequently extended by via Ruggero Settimo and via Libertà;

- via Roma, built in the nineteenth century after the partial demolition of the historic fabric, has always been a shopping street (retail shops and department stores) with tertiary function (there are many office buildings) but it has been facing a deep crisis for several years;

- via Calderai, where craft activities as metalworking are traditionally located, nevertheless they have been partly replaced by other businesses managed by immigrants;

- via Ponticello is a street to get to the Ballarò market;

- Ballarò market, historical outdoor market for the sale of foodstuffs;

- via Bara all'Olivella - via dell'Orologio are streets where restaurants are prevalently located.

A total of 1130 retail properties were analyzed from the point of view of the current use (used/unused), the type of goods sell (non-food/foodstuff) and the geographical origin of the tenants (continent).

A first datum that emerges (Fig. 8) is the share of unused properties that is more than a fifth of the total $(22 \%)$. This value is quite high considering that they are the main streets of the historic centre where the commercial function is historically rooted. The demand of real estate for catering activities (bars, fast-food restaurants, pubs and restaurants) is $30 \%$, while the presence of immigrants is $12 \%$ of the sample, with a strong prevalence of Asians $(11 \%)$ and a small presence of Africans (1\%) (Fig. 9).

The comparison of the data referred to via Maqueda and via Roma (Figg. 10 and 11) makes it possible to evaluate the opposite outcomes consequent to the provisions of the Municipal Administration regarding the pedestrianization and the Limited Traffic Zones (ZTL). Although both streets fall within the ZTL perimeter, via Maqueda is a pedestrian street from piazza Verdi to piazza Vigliena (where it connects to the pedestrian area of corso Vittorio Emanuele); on the contrary, via Roma remains a driveway. These decisions have created the conditions for the resumption of demand for the lease of new retail shops in the pedestrian area of Via Maqueda, and have also favored the immediate replacement (without any vacancy) of some declining shops with catering activities. Via Roma, on the other hand, has been penalized by the restrict accessibility, accentuating its ongoing decline as shopping street that has caused an increase in unused buildings and very long vacancy time (even more than one year). In via Roma the percentage of empty commercial 


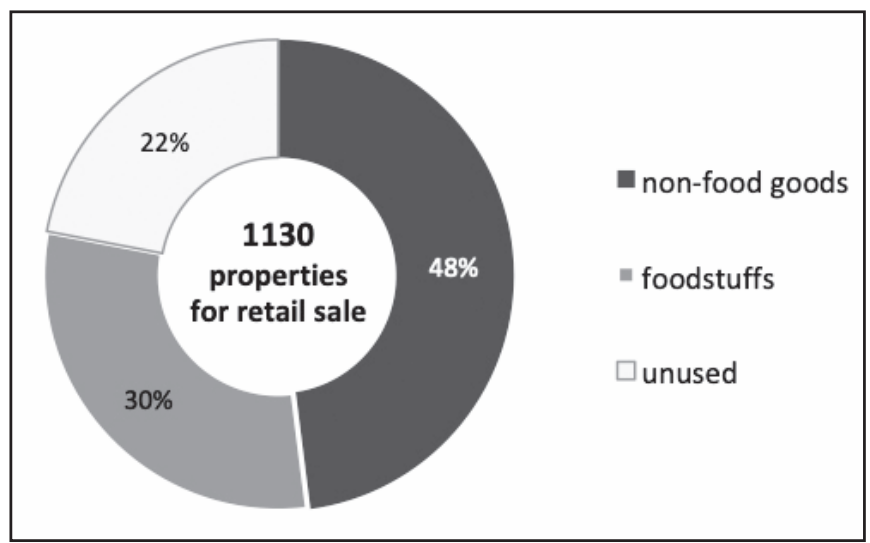

Figure 8 - Use of retail real estate in the case study.

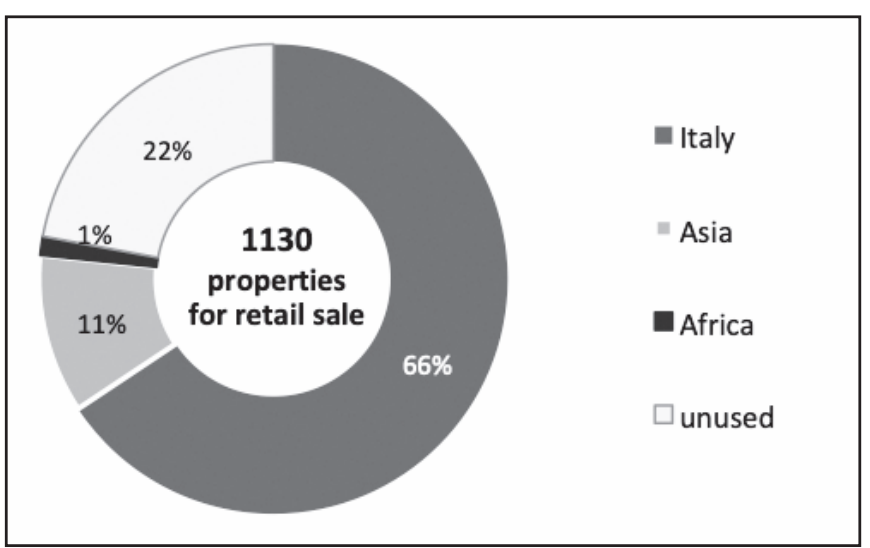

Figure 9 - Geographical origin of the tenants in the case study.

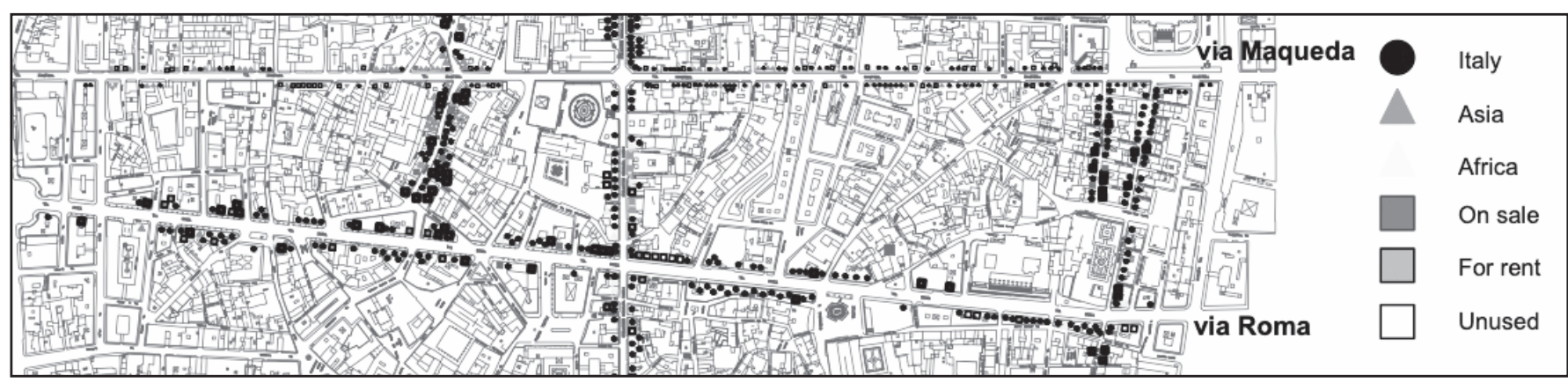

Figure 10 - Location of retail shops in via Roma and via Maqueda.

properties is high and equal to $35 \%$, in addition the properties rented to foreigners are a very small number. In via Maqueda, on the contrary, nevertheless a quote of unused retail properties $(19 \%)$, there is a large presence of shops managed by migrants that is equal to $20 \%$. The immigrants are mainly Asians (especially Bangladeshis) who intercept the consumption needs of young people, tourists and residents by selling foodstuffs during extended opening hours.

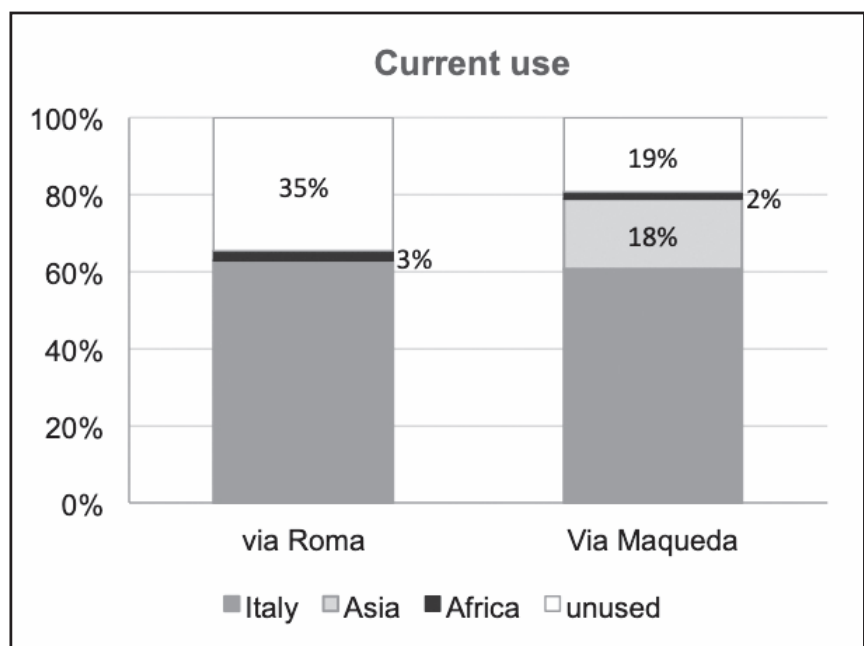

Figure 11 - Geographical origin of the tenants in the case study in via Roma e via Maqueda.
However, it is noteworthy that the commercial properties leased to immigrants are located mainly in the section of via Maqueda between piazza Vigliena and piazza Giulio Cesare - which has remained open to vehicular transit until July 2019 - where rents are low and vary between 93 and 480 euros/sq.m./year, according to a direct survey in 2018, even if the most frequent values fluctuate between 100 and 200 euros/sq.m./year (Fig. 12). The presence of activities managed by immigrants becomes increasingly

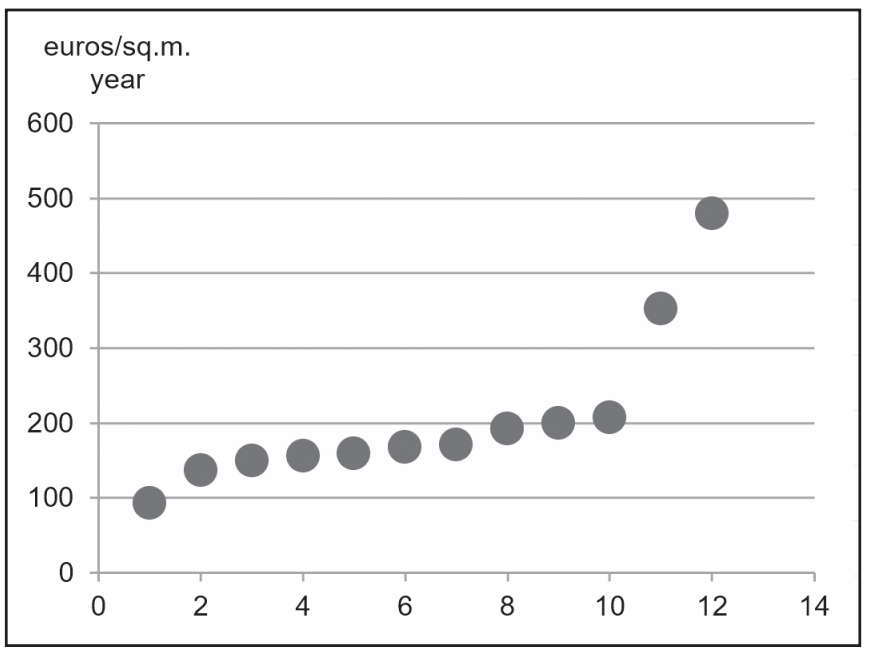

Figure 12 - Unit rent of retail properties in Via Maqueda (from Piazza Vigliena to Piazza Giulio Cesare) (direct survey in 2018). 
The urban rent in the multicultural city: retail shops, migrants and urban decline in the historic centre of Palermo

sporadic as we proceed towards the city center (Piazza Giuseppe Verdi) where the high rents constitute an economic barrier to their location.

\section{CONCLUSIONS}

The modification of the localization patterns of retail properties due to the spread of new retail sales (shopping malls, megastores, e-commerce websites) has deeply affected the urban fabric and has led to the reorganization of the urban real estate market in terms of liquidity transmutation, demand/supply and values/income relations. Even the central areas of the city and the high streets may suffer a relative decline with long vacancy time caused by excess supply of retail property for rent.

These transformations, at the same time, give the opportunity to intensify the social interactions and the rooting in the districts of the immigrants, as they play a significant role in supporting the demand for rental of residential and commercial real estate and in mitigating the rent decrease.

The analysis of the case study, formed by some high streets in the historic centre of Palermo, made it possible to verify that the rental demand for retail properties expressed by immigrants is not the result of a mere replacement of tenants, but is a real increment of demand for properties that would otherwise remain unused causing additional minus-valuations and a significantly reduction of profitability of real estate assets.

Besides it is important to underline that these retail shops are not only a place of exchange of goods where profit and income are generated, but they become places of social interaction and gathering that are fundamental for building of a contemporary multicultural city.

* Grazia Napoli, Department of Architecture, University of Palermo e-mail: grazia.napoli@unipa.it

** Giulia Bonafede, Department of Architecture, University of Palermo

e-mail: giulia.bonafede@unipa.it

\section{Bibliography}

Abbate G., Orlando M., Centri commerciali a Palermo: alla conquista della Conca d'Oro, in Leone M., Lo Piccolo F., Schilleci F. (a cura di), Il paesaggio agricolo della Conca d'Oro di Palermo, Alinea Editrice, Firenze, 2009, pp. 305313.

Appadural A., Modernità in Polvere, Meltemi, Roma, 2001. ARENDT H., The Human Condition, Chicago University Press, Chicago, 1958.

Augé M., Nonluoghi. Introduzione ad una antropologia della surmodernità, Eleuthera, Milano, 2009.

BARONI W., Contro l'intercultura. Retoriche e pornografia dell'incontro, Ombre corte, Verona, 2013.

Bazzı A., La piazza è mia, Rubbettino, Catanzaro, 2012.

Bonafede G., Lo Piccolo F., Cronache ZEN: la questione abitativa tra assenza di politiche pubbliche, pratiche dal basso ed arte della negoziazione, Archivio di Studi Urbani e Regionali, No. 90, 2007, pp. 47-66.

Bonafede G., Napoli G., Palermo multiculturale tra rischi di gentrification e crisi del mercato immobiliare nel centro storico, Archivio di Studi Urbani e Regionali, No. 113, 2015, pp. 123-150.

Bonafede G., Napoli G., Erraticism and Multicultural Permeability of Urban Fabric in Palermo, in Piccinini L.C., Chang T.F.M., Taverna M., Iseppi L. (eds.), The Erratic Behavior of the Landscape-cultural Mosaic: Emotion, Energy, Experience, Proceedings of the 20th
IPSAPA/ISPALEM International Scientific Conference, Reggio Calabria (Italy) July 7th-8th, 2016, 2017, pp. 139-150.

Bonafede G., SChilleCl F., "Frantumazione e armonia: dinamiche della "diluizione" urbana nella Piana dei Colli di Palermo", in Leone M., Lo Piccolo F., Schilleci F. (a cura di), Il paesaggio agricolo nella Conca d'Oro di Palermo, Alinea Editrice, Firenze, 2009, pp. 293-304.

Camagni, R., Economia urbana. Principi e modelli teorici, La Nuova Italia Scientifica, Roma, 1992.

CAnNarozzo T., "La governance mafiosa e l'assalto al territorio", in Leone M., Lo Piccolo F., Schilleci F. (a cura di), II paesaggio agricolo nella Conca d'Oro di Palermo, Alinea, Firenze, 2009.

Ciuna M., Milazzo L., Salvo F., A mass appraisal model based on market segment parameters, Buildings, Vol. 7(34), 2017, pp. 1-13.

Crosta P.L., Società e territorio, al plurale. Lo "spazio pubblico" - quale bene pubblico - come esito eventuale dell'interazione sociale, Foedus, No. 1, 2000, pp. 40-53.

DAMESICK P., E-commerce and UK retail property: Trends and issues, Briefings in Real Estate Finance, Vol. 1, No. 1, 2001, pp. 18-27.

Forte F., Antoniucci V., De PaOla P., Immigration and the Housing Market: the Case of Castelvolturno in Campania Region, Italy, Sustainability, No. 10, issue 343, 2018, pp. 1-17. Giampino A., Picone M., SChilleCi F., The shopping malls as an emergent public space in Palermo, The journal of 
Public Space, No. 2, 2017, pp. 85-96.

Giuffrida S., Ventura V., Trovato M.R., Napoli G., Axiology of the historical city and the cap rate. The case of the old town of Ragusa Superiore, Valori e Valutazioni, No. 18, 2017, pp. 41-55.

Holston J., "Spaces of Insurgent Citizenship", in Sandercock L. (ed.), Making the Invisible Visible. A Multicultural Planning History, University of California Press, Berkeley, Los Angeles, 1998.

Marotta P., SchilleCi F., "Il controverso ruolo dei centri commerciali per la definizione dello spazio pubblico nella trasformazione della città contemporanea", in Schilleci F., Lo Piccolo F. (a cura di), Forme e processi per il progetto di territori. Pratiche e prospettive nella Sicilia occidentale, FrancoAngeli, Milano, 2016, pp. 106-119.

Moccia F.D., Sgовво A., La polarizzazione metropolitana: I'evoluzione della rete della grande distribuzione verso un sistema policentrico sostenibile, Liguori Editore, Napoli, 2013.

NAPOLI G., "Financial sustainability and morphogenesis of urban transformation project", in Gervasi O., Murgante, B., Misra, S., Gavrilova, M.L. Rocha A.M.A.C., Torre C., Tanjar D., Apduhan B.O. (eds.) ICCSA 2015, Part III, LNCS No. 9157, 2015, pp. 178-193.

NAPOLI G., Housing affordability in metropolitan areas. The Application of a Combination of the Ratio Income and Residual Approaches to Two Case Studies in Sicily, Italy, Buildings, Vol. 7(4), No. 95, 2017, pp. 1-19.

NAPOl G., VAlenti A., Giuffrida S., "The urban landscape and the real estate market. Structure and fragment of the axiological tessitura in a wide urban area of Palermo", in Piccinini L.C., Chang T.F.M., Taverna M., Iseppi L. (eds.), The Turning Point of the Landscape-cultural Mosaic: Renaissance Revelation Resilienc, Proceedings of the 19th IPSAPA/ISPALEM International Scientific Conference, Napoli (Italy) July 2nd-3rd, 2015, 2016a, pp. 67-78.

Napoli G., Giuffrida S., Trovato M.R., "Fair Planning and Affordability Housing in Urban Policy. The Case of Syracuse (Italy)", in Gervasi, O. et al. (eds.), Computational Science and Its Applications, Vol. 9789, 2016b, pp. 46-62.
NAPOl G., Giuffrida S., VAlenti A., "Forms and functions of the real estate market of Palermo. Science and knowledge in the cluster analysis approach", in Stanghellini S., Morano P., Bottero M., Oppio A. (eds.), Appraisal: from Theory to Practice, Results of SIEV 2015, Springer International Publishing, 2017a, pp. 191-202.

Napoli G., Giuffrida S., Trovato M.R., Valenti A., Cap rate as the interpretative variable of the urban real estate capital asset: A comparison of different sub-market definitions in Palermo, Italy, Buildings, Vol. 7(3), No. 80, 2017b, pp. 1-25.

RızzO F., II capitale sociale della città, FrancoAngeli, Milano, 2003.

SANDERCOCK L., Toward Cosmopolis. Planning for Multicultural Cities, Wiley, Chichester, 1998.

SANDERCOCK L., When Strangers Become Neighbours: Managing Cities of Difference, Planning Theory and Practice, Vol. 1, No. 1, 2000, pp.13-30.

SASSEN S., Whose Cities Is It? Globalization and the Formation of New Claims, Public Culture, No. 8, 1996, pp. 205-223.

Sassen S., The Global City, New York, London Tokyo, Princeton University Press, Princeton, NJ, 2001.

ScotT A.J. Città e regioni nel nuovo capitalismo. L'economia sociale delle metropoli, Il Mulino, Bologna, 2011.

SojA E.W., Beyond Postmetropolis, Urban Geography, Vol. 32, No. 4, 2011, pp.451-46.

Soja E.W., Postmetropolis: Critical studies of Cities and Regions, Blackwell Publishers, Oxford-Malden (MA), 2000.

TODARO V., "Fenomeni di differenziazione sociale", in Vinci I., La Greca P. (a cura di), Sicilia. Rapporto sul territorio 2018, Urbanistica Dossier, No. 16, 2018, pp. 21-25.

Weltevreden J.W.W., Van RietberGer T., E-shopping versus city centre shopping: The role of perceived city centre attractiveness, Economische en Sociale Geografie, Vol. 98, No. 1, 2007, pp. 68-85.

YounG, I. M., Justice and the Politics of Difference. Princeton University Press, Princeton, NJ, 1990. 


\title{
La rendita urbana nella città
} multiculturale: attività commerciali, migranti e declino urbano nel centro storico di Palermo

Grazia Napoli*, Giulia Bonafede** parole chiave: rendita; retail; migranti; città multiculturale; mercato immobiliare; centro storico

\begin{abstract}
La diffusione di nuove modalità di vendita al dettaglio, come gli shopping mall, i megastore e l'e-commerce, hanno modificato i tradizionali modelli localizzativi di immobili a destinazione commerciale, incidendo anche sulle connotazioni del tessuto urbano ed extraurbano e sulla distribuzione spaziale della rendita. Anche le zone centrali delle città hanno subito trasformazioni significative, che a volte si traducono in un vero e proprio declino, soprattutto in presenza di sistemi economici locali deboli e di mercati immobiliari in recessione. Una quota rilevante di immobili a destinazione commerciale può rimanere a lungo non utilizzata per eccesso di offerta sulla domanda, poiché a fronte della cessazione di molte attività commerciali tradizionali, che non riescono più ad essere competitive, non si registra un subentro immediato da parte di nuovi soggetti economici. Il declino dei luoghi urbani centrali dipende dall'intreccio di molteplici fattori economici, sociali, culturali, ma

può essere contrastato da politiche urbane orientate non soltanto alla riqualificazione fisica del tessuto urbano, ma anche al supporto di processi di coesione sociale e di multiculturalità. I migranti, provenienti da continenti diversi e portatori di modelli culturali variegati, insediandosi stabilmente nella città italiane, hanno colmato alcuni di questi vuoti localizzandovi attività di vendita al dettaglio o di erogazione di servizi rivolte in modo specifico alle loro comunità di appartenenza, oppure aperte all'intera cittadinanza. La loro presenza contribuisce, di fatto, a sostenere la domanda di immobili a destinazione commerciale, ad attenuare le minus-valorizzazioni del capitale immobiliare e a contenere la contrazione delle rendite. Questo fenomeno è stato analizzato a Palermo in alcuni assi viari del centro storico tradizionalmente vocati al commercio e diventati il luogo privilegiato di localizzazione di attività commerciali gestite da immigrati.
\end{abstract}




\section{INTRODUZIONE}

La diffusione di modalità differenziate di commercio al dettaglio e di altri servizi (shopping mall, megastore, ecommerce, ecc.), in conseguenza del processo di globalizzazione dell'economia, ha inciso profondamente sulla trasformazione delle città e dei sistemi territoriali anche dal punto di vista del mercato di immobili a destinazione commerciale con implicazioni che investono i modelli di localizzazione residenziale e la sfera delle relazioni multiculturali.

Le nuove modalità di retail hanno, infatti, prodotto fenomeni di polarizzazione socio-economica contribuendo, soprattutto in aree geografiche con economia debole e stagnazione del mercato immobiliare, al declino del tessuto commerciale diffuso anche nelle aree centrali delle città, come accade in molte realtà siciliane. Queste aree in declino si sono mostrate permeabili alla localizzazione di attività economiche gestite dai migranti in seguito al consolidamento dell'insediamento residenziale stanziale di comunità di cittadini stranieri (Bonafede e Napoli, 2016; Forte et al., 2018).

Sebbene negli ultimi anni si sia registrata una grande affluenza di migranti nelle aree rurali siciliane contrassegnate da colture intensive, le città di Palermo, Messina e Catania continuano a rappresentare i principali poli attrattori a scala regionale dei flussi migratori per la presenza di maggiori opportunità lavorative (Todaro, 2018) legate perlopiù alle attività commerciali e alla cura domestica.

Come uno degli effetti delle complesse dinamiche globali, i flussi migratori hanno effettivamente sfidato città di grandi e piccole dimensioni e intere regioni urbane nella costruzione di nuovi modelli di sviluppo interculturale. Questi flussi transazionali di persone hanno evidenziato molte contraddizioni culturali, oltre che in varie politiche economiche e sociali coinvolte, anche nella pianificazione urbanistica (Sassen, 1996 e 2001; Sandercock, 1998 e 2000), che talvolta interagisce con altri studi (antropologici, etnografici, geografici e post-coloniali) al fine di esplorare in modo più incisivo i territori delle differenze e dei loro diritti (Appadurai, 2001; Baroni, 2013; Holston, 1998; Young, 1990; Soja, 2007; Scott, 2011).

In alternativa alla proliferazione di mercati e spazi pubblici virtuali, le scelte di localizzazione dei migranti in aree centrali ma connotate da prezzi bassi delle abitazioni e dei negozi, possono essere considerate delle opportunità per avviare in controtendenza un nuovo tipo di rivitalizzazione urbana incentrato sulle relazioni interculturali e ancorato nello spazio fisico della città.

Da questo punto di vista, la ricerca indaga in quali termini la presenza degli immigranti contribuisce a sostenere la domanda di immobili a destinazione commerciale e a contenere la diminuzione delle rendite, analizzando il caso del centro storico di Palermo, in un quadro d'interdipendenza degli effetti indotti dalla diffusione di megastore o centri commerciali in altre parti della città.

Inoltre, questo studio sottolinea i valori multiculturali emergenti dal lento processo di costruzione dello spazio pubblico come risultato d'interazioni sociali che sono ancorate nel tessuto urbano in comparazione con lo spazio chiuso e predeterminato dei centri commerciali.

\section{COMMERCIO GLOBALE E SPAZIO URBANO}

Le relazioni complesse tra comunità sociali (diverse per reddito, modelli culturali, provenienze geografiche), luoghi (centro e centralità, periferie e marginalità) e funzioni (complementari, sinergiche e conflittuali) sono sottoposte a una continua tensione tra cambiamento e persistenza in cui si manifestano le capacità di resilienza della città che le consentono di trasformarsi pur mantenendo la propria identità.

I modelli localizzativi delle attività commerciali sono sempre stati un elemento costitutivo della struttura urbana, dalla piazza-mercato al centro della città agli shopping mall che trasformano vaste aree periferiche o extraurbane in luoghi dedicati esclusivamente al consumo.

Emblemi del commercio globalizzato, gli shopping mall, nati negli USA negli anni ' 20 ma sviluppatisi in Europa a cominciare dagli anni '70 del secolo scorso, hanno avuto una grande espansione per l'offerta di prodotti a prezzi bassi localizzandosi inizialmente in aree urbane centrali con edifici multipiano (Moccia e Sgobbi, 2013). Agli inizi del nuovo millennio i nuovi modelli si sono evoluti in strutture sempre più estese e articolate localizzandosi, come nodi di un sistema reticolare a larga scala, in aree periferiche servite da grandi parcheggi e da svincoli viari e autostradali.

Alle principali superfici destinate alla vendita al dettaglio dei prodotti (Gross Leasable Areas) si sono aggiunte, durante questa evoluzione, molteplici funzioni d'intrattenimento culturale, sportivo e ricreativo (cinema, sale convegni, palestre, aree giochi), così come attività di servizio (sportelli bancari, poste) e di ristorazione (bar, fast food, ristoranti). Il tentativo è quello di costruire ex-novo una nuova polarità in posizione periferica in cui concentrare le attività solitamente localizzate negli spazi pubblici (strade, piazze, gallerie) dei centri delle città che nei mall diventano spazi privati aperti alla fruizione pubblica al solo fine di supportare l'attività di consumo.

In questo tipo di spazi globalizzanti, I'appiattimento e l'omogeneizzazione delle attitudini relazionali (Augé, 2009), hanno alimentato la riflessione critica sul concetto di spazio pubblico e la sua contrazione in favore di quello privato. I nuovi shopping mall sono stati definiti "pseudo spazi pubblici" (Giampino et al., 2017) poiché suppliscono alla mancanza di spazi di aggregazione come esito di un prodotto precostituito piuttosto che di un "costrutto sociale", come risulta invece da un processo d'interazione sociale (Crosta, 2000). Sono stati definiti anche "non luoghi" poiché non dialogano con il paesaggio e lo spazio urbano circostante rinchiusi in "città mondo" senza né storia né identità (Augé, 2009). 
La rendita urbana nella città multiculturale: attività commerciali, migranti e declino urbano nel centro storico di Palermo

Il centro commerciale indubbiamente attira diversi tipi di persone e di generazioni e specialmente durante i weekend può essere considerato come una delle "urban glamour zones" non solo nella rete delle principali città globali (Sassen, 1996 e 2001), ma anche nelle periferie globalizzate.

Negli Stati Uniti si registra già da tempo il fenomeno dei "dead mall", che sono studiati per comprenderne le cause del fallimento e per intervenire con progetti di riconversione in chiave sostenibile (Moccia e Sgobbi, 2013). Sono già stati realizzati interventi di "de-malling" ritornando, paradossalmente, ai modelli insediativi del tessuto storico urbano con la previsione di mix funzionali (residenze, uffici, negozi e attività ricreative) e riportando lo scambio e gli spazi del commercio alle modalità persistenti da secoli, ovvero in spazi aperti oppure in negozi prospicenti le strade. In questa prospettiva ampi parcheggi di automobili sono stati riconvertiti in parchi pubblici, con notevole dispendio per il ripristino del terreno vegetale.

Gli shopping mall si sono diffusi nel territorio siciliano con ritardo rispetto ad altre aree geografiche e sono stati adombrati talvolta dal sospetto di costituire un mezzo per riciclare i proventi di dubbie attività economiche (Cannarozzo, 2009; Bazzi, 2012). A Palermo, in particolare, queste strutture sono state dislocate in prossimità di borgate storiche e quartieri periferici di Edilizia Residenziale Pubblica (ERP) connotati da elevati tassi di disagio sociale (elevata disoccupazione, diffusa dispersione scolastica e bassi livelli dei redditi).

Propagandati come panacea per riqualificare aree a rischio di esclusione e per sopperire alla mancanza di attrezzature e servizi pubblici, i tre principali shopping mall di Palermo ("La Torre" nel quartiere Borgonuovo, "Conca d'Oro" allo Zen e "Il Forum" a Brancaccio) sono stati costruiti dal 2006 in variante agli strumenti urbanistici vigenti e a seguito di programmi negoziati tra I'Amministrazione Comunale e gli investitori privati, coinvolti nella realizzazione di strutture d'interesse collettivo che non sempre sono state eseguite o che si sono rivelate irrilevanti per le necessità della popolazione locale (Bonafede e Lo Piccolo, 2007; Abbate e Orlando, 2009).

La scelta di localizzare i mall nelle frange urbane non ha soltanto contribuito a erodere ampie estensioni di suolo agricolo, talvolta connotato da colture di pregio ambientale, interrompendo potenziali connessioni ecologiche e sociali tra varie parti della città (Bonafede e Schilleci, 2009; Marotta e Schilleci 2016), ma ha anche causato impatti negativi sui centri commerciali "naturali" che si erano plasmati nel tempo, soprattutto nel Centro Storico. Infatti, le grandi dimensioni dei mall, oltre a generare fenomeni di spaesamento rispetto al paesaggio agrumicolo e alle minute dimensioni delle borgate agricole limitrofe, hanno causato il declino di preesistenti attività commerciali, tradizionalmente dislocate in vari negozi o in mercati all'aperto del tessuto urbano e del Centro Storico in particolare, con controverse conseguenze sull'effettivo incremento del nu- mero complessivo di addetti in questo settore, propagandato come uno dei vantaggi ottenuti ${ }^{1}$.

\section{SPAZIO URBANO E MIGRANTI}

Le ricadute, senz'altro negative, sulle attività commerciali tradizionali si registrano soprattutto nel Centro Storico in concomitanza con l'inefficacia delle politiche di recupero urbano che non sono riuscite a supportare adeguatamente le fasce di popolazione a basso reddito e i piccoli proprietari immobiliari (Bonafede e Napoli, 2015), incidendo negativamente sulla manutenzione dei tessuti urbani, i loro valori economici e la loro vivacità.

Lo svuotamento delle funzioni terziarie di importanti assi, come quello di via Roma e via Maqueda, così come il declino di alcuni mercati storici (la Vucciria), hanno tuttavia offerto nuove opportunità di relazioni interculturali attivando processi di sostituzione nei vuoti lasciati dalle attività commerciali e residenziali abbandonate dagli "italiani", che hanno facilitato la concentrazione nel Centro Storico di migranti originari da differenti nazioni e favorito un lento processo di filtering up.

In periodi di perdurante crisi economica, gli immigranti hanno pertanto contribuito a mantenere in uso gli edifici del centro storico, a sostenere la domanda di immobili a destinazione residenziale e commerciale, attenuando le trasformazioni della struttura del mercato immobiliare (Napoli et al., 2016a; Napoli et al., 2017a; Ciuna et al., 2017) e le difficoltà a individuare usi alternativi economicamente convenienti (Napoli, 2015), e talvolta a resistere a processi, sia pure sporadici e frammentari, di gentrification (Bonafede e Napoli, 2015).

Questa resilienza della città multiculturale, intesa come capacità di rispondere a crisi urbane mantenendo in equilibrio il sistema con modalità innovative, è stata indagata non solo in termini di valori di mercato del capitale immobiliare, ma anche con riguardo ai valori che si attribuiscono ai processi di costruzione dello spazio pubblico e degli spazi privati aperti alla fruizione pubblica.

Il variegato sistema di attività commerciali e di servizi che i migranti offrono alle loro comunità e che, al contempo, sono rivolte all'intera cittadinanza sono, infatti, occasione di aggregazione e d'interazione culturale e contribuiscono a costituire "gli occhi della strada" garantendo anche una maggiore sicurezza. Viceversa, i numerosi servizi di accoglienza e formazione di supporto ai gruppi di migranti presenti nel Centro Storico, come il Centro Astalli e Santa Chiara, diventano crocevia di eventi solidali, rinsaldando le interazioni culturali.

Se lo spazio pubblico è preminentemente uno spazio re-

\footnotetext{
1 Uno studio rileva che a Palermo, dal 2006 al 2012, a fronte di un numero crescente di nuovi dipendenti dei centri commerciali, il totale degli operatori nel settore del commercio diminuisce (tesi di U. Pera, a.a. 2013/14, relatore G. Bonafede).
} 
lazionale (Arendt, 1958) e se questo è un "costrutto" (Crosta, 2000), ossia l'esito di una costruzione nel tempo e nello spazio fisico di interazioni sociali (piuttosto che un prodotto preconfezionato), le modalità attraverso le quali il centro storico di Palermo si rende permeabile alla residenza e alle attività commerciali offerte dai gruppi di migranti esprimono, a nostro avviso, l'inizio di un processo di costruzione di valori multiculturali che sono da salvaguardare con politiche idonee. Il tessuto di interazioni, infatti, ha già creato in questo modo uno spazio pubblico, dove le differenze si riconoscono, si rispettano e si apprende reciprocamente.

\section{RENDITA E CAPITALE IMMOBILIARE COMMERCIALE}

Le città sono il luogo privilegiato dello scambio, non soltanto di beni materiali, ma anche di valori monetari, simbolici, culturali, etici e estetici. La forma monetaria della città (Rizzo, 2003), ovvero l'organizzazione spaziale della rendita, costituisce di fatto la traduzione delle gerarchie, centralità e polarità della città in valori, incorporando le economie di agglomerazione, i diversi gradi di accessibilità e le potenzialità di interazione dei luoghi (Camagni, 1992). Dato che l'offerta di immobili urbani è rigida nel breve periodo perché vincolata alle previsioni degli strumenti urbanistici, variazioni delle quantità di beni immobili tali da influenzare i prezzi si ottengono solamente nel medio-lungo periodo attraverso la redazione di nuovi piani oppure di interventi di riqualificazione urbana in deroga agli strumenti vigenti.

La realizzazione dei centri commerciali ha comportato un significativo aumento dell'offerta di immobili a destinazione commerciale in mercati locali in cui è intervenuta una consistente contrazione della domanda riguardante le sedi dei negozi tradizionali. Questa contrazione si è successivamente estesa anche agli spazi negli store e negli stessi centri commerciali, provocando l'aumento dei tempi di vacancy degli immobili in locazione e la minusvalorizzazione degli immobili in vendita.

La diffusione dell'e-commerce su scala globale, inoltre, spostando l'acquisto di molte tipologie di beni e servizi, dal luogo fisico dello scambio (negozio) a un luogo astratto (web), ha causato la cessazione di numerose attività commerciali tradizionali che erano in difficoltà a causa della riduzione di redditi e consumi. L'intensificarsi della concorrenza ha infatti generato la diminuzione dei prezzi dei prodotti, I'assottigliamento dei margini di profitto e ha inciso negativamente sulla sostenibilità dei canoni di locazione (Damesick, 2001). Gli immobili commerciali presentano, quindi, un diverso grado di rischio economico dei redditi e del valore capitale in dipendenza di molteplici fattori: tipologia di attività commerciale, specifica localizzazione urbana, dimensione e rango della città, ampiezza del bacino di fruitori potenziali, caratteristiche edilizie e tecnologiche dell'immobile stesso (dimensione, stato di conservazione, presenza di vincoli).
Come contromisura a questo declino, alcuni brand internazionali stanno proponendo esperienze sensoriali uniche e personalizzate per rimanere competitivi e come strumento per attirare il consumatore nel luogo fisico del negozio e sottrarlo all'acquisto impersonale sulla rete. In questi casi la domanda di immobili si rafforza anche se ciò, per il momento, tende a riguardare prevalentemente le "high street", ovvero le strade centrali in cui si concentrano negozi o catene di abbigliamento low budget o di alta gamma (alta moda o high tech) e negozi multibrand.

Nonostante l'e-commerce induca tendenzialmente la riduzione del numero degli spostamenti per gli acquisti verso il centro città (e i centri commerciali), alcuni studi (Weltevreden e von Rietbergen, 2006) hanno verificato che se il centro città è percepito come un luogo attrattivo sia in termini di convenienza dei prezzi, sia in termini di buona accessibilità, molti cittadini sono invogliati ad acquistare in centro piuttosto che su internet. Questo è un risultato incoraggiante per la promozione di politiche di valorizzazione dei centri storici e di supporto alla permanenza delle attività commerciali.

Il mercato degli immobili a destinazione commerciale in Italia ha mostrato negli ultimi anni un significativo incremento del Numero delle Transazioni Normalizzate (NTN), anche se I'intensificazione degli scambi non ha ancora innescato l'aumento sistematico dei prezzi.

L'analisi dei dati OMI relativi all'NTN e alle quotazioni (Rapporto 2018 su dati 2017) mostra un quadro diversificato, se si comparano le variazioni percentuali medie nazionali e regionali con quelle relative ad alcune città capoluogo (Fig. 1), dovuto al fatto che il grado di resilienza dei mercati immobiliari locali sottoposti a perturbazioni interne ed esterne dipende dalla peculiare combinazione creativa di fattori micro e macro economici e micro e macro territoriali, e fornisce, quindi, esiti sempre differenti.

A fronte di una variazione media nazionale dell'NTN di

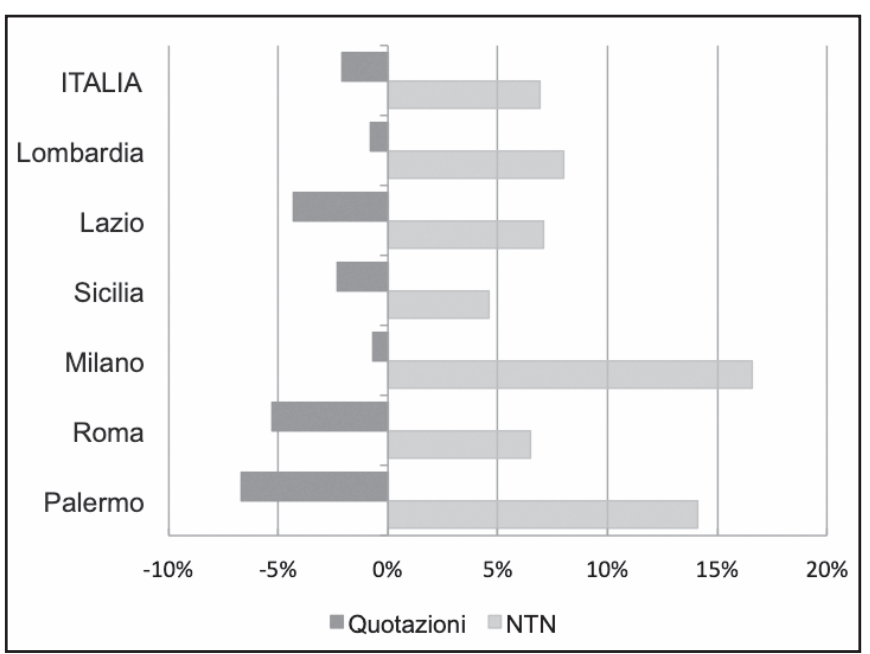

Figura 1 - Variazione percentuale delle quotazioni e dell'NTN 2016-2017 (ns elaborazione su dati OMI). 
La rendita urbana nella città multiculturale: attività commerciali, migranti e declino urbano nel centro storico di Palermo

$+6,9 \%$, le regioni Lombardia e Lazio presentano valori molto simili, mentre il dato è molto più basso per la Sicilia dove si raggiunge solamente $+4,6 \%$. Esiste un grande divario tra i dati medi regionali e quelli registrati nelle rispettive città capoluogo, infatti a Milano e Palermo I'NTN si è incrementato rispettivamente di $+16,6 \%$ e $+14,1 \%$, evidenziando l'effetto polarizzante delle città metropolitane sulla localizzazione delle attività commerciali rispetto al territorio regionale. Al contrario la variazione dell'NTN a Roma è leggermente inferiore a quella media del Lazio.

L'analisi dell'andamento delle quotazioni medie, tuttavia, non fornisce sempre risultati speculari rispetto a quelli dell'NTN. Il dato comune che emerge è la permanenza della minus-valorizzazione generalizzata del capitale immobiliare commerciale che, in termini di media nazionale, è pari a $-2,1 \%$. Nel raffronto tra le quotazioni di Lombardia e Lazio e la media nazionale si osserva una divaricazione, infatti le quotazioni scendono del doppio nel Lazio (-4,3\%) e hanno appena una leggera flessione in Lombardia $(-0,8 \%)$, mentre risultano quasi allineate ai valori nazionali in Sicilia $(-2,3 \%)$.

La riduzione delle quotazioni è ancora più intensa a Roma $(-5,35 \%)$, ma è interessante rilevare l'andamento di Milano e Palermo. Nonostante la netta ripresa delle transazioni in entrambe le città, le conseguenze sulle quotazioni sono diametralmente opposte.

A Milano le quotazioni diminuiscono leggermente $(-0,7 \%)$, mostrando come una maggiore intensità degli scambi abbia consentito di non dilatare i margini di contrattazione e di cedere poco terreno sul livello dei prezzi. In questo caso siamo presumibilmente in presenza di una domanda disposta a pagare ancora prezzi elevati perché si aspetta di ottenere una buona redditività a lungo termine dell'investimento, sia in termini di possibilità di locazione, sia in termini di future plus-valorizzazioni (Giuffrida et al., 2017; Napoli et al., 2017b). A Palermo, invece, all'intensificazione degli scambi corrisponde una ulteriore consistente riduzione dei prezzi $(-6,7 \%)$ che è indicativa di un mercato urbano in cui permane un eccesso di offerta rispetto alla domanda e in cui il basso grado di liquidità degli immobili a destinazione commerciale si traduce in transazioni con alta perdita di valore e con lunghi tempi di attesa di un acquirente.

I dati su NTN e quotazioni medie sono utili per conoscere il quadro complessivo entro cui si muove il mercato immobiliare, anche se la forma monetaria (prezzi e redditi) delle localizzazioni commerciali assume connotazioni specifiche e sempre differenti in ogni sistema urbano.

A scala urbana, un segmento di mercato singolare è quello formato dalle "high street", nelle quali le tendenze globali o nazionali del mercato immobiliare vengono spesso anticipate e amplificate, e in cui possono registrarsi anche trend in controtendenza rispetto a ciò che accade nel resto della città.

Nella Figura 2 è confrontato l'ordine di grandezza delle quotazioni minime e massime delle locazioni annue di alcune high street nelle città di Milano, Roma e Palermo.
I valori unitari di locazione più elevati sono rilevati in via Monte Napoleone (con un picco di 9.800 euro/mq anno) e in via della Spiga a Milano, e anche in via dei Condotti a Roma (8.000 euro/mq anno), ovvero nei luoghi dedicati prevalentemente agli acquisti di turisti stranieri dove è massimo il valore simbolico e di rappresentanza del lusso e del design italiano e dei grandi brand internazionali.

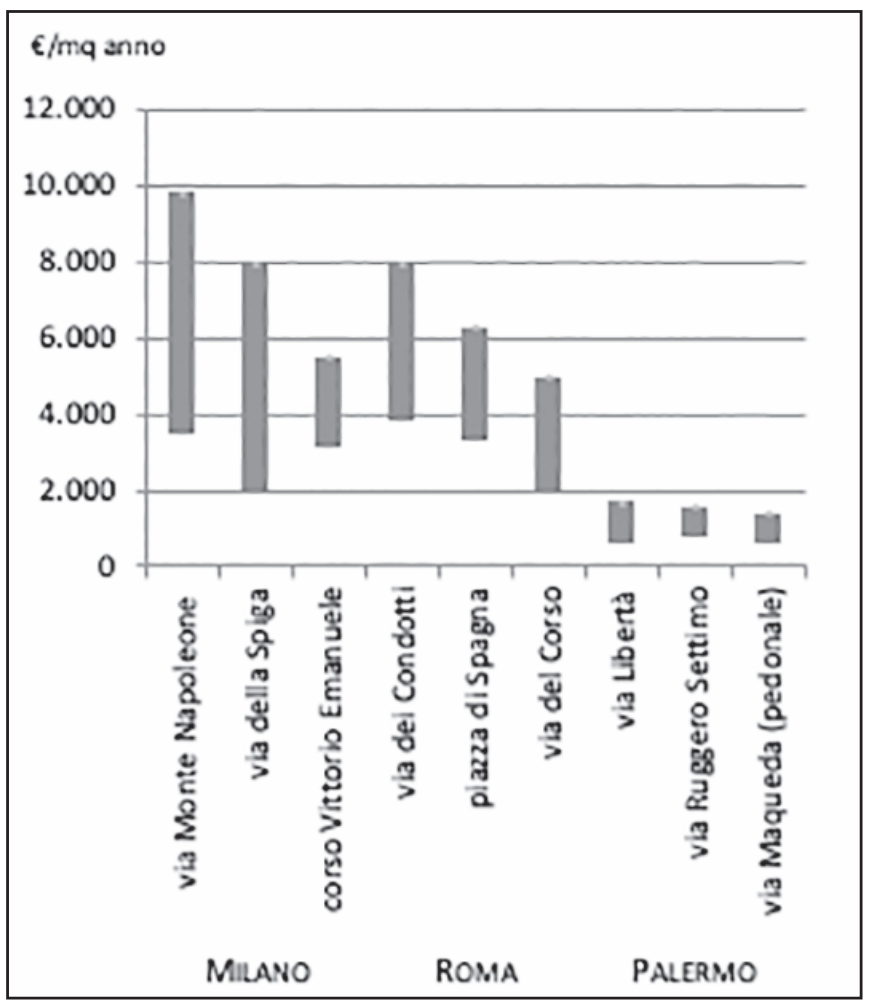

Figura 2 - Valori di locazione in alcune high street a Milano, Roma e Palermo (elaborazione su dati 2016, World Capital Real Estate Group).

Il più importante asse viario di Palermo è formato in successione da via Maqueda che coincide con una delle vie principali del centro storico di impianto cinquecentesco, via Ruggero Settimo che attraversa la prima espansione settecentesca della città fuori dalle mura, e via Libertà che continua lungo la direttrice di espansione nord nei quartieri destinati all'alta borghesia e alla nobiltà sorti tra la fine dell' 800 e i primi decenni del ‘'900.

In questa high street (che include però solamente il tratto di via Maqueda tra piazza Verdi e piazza Vigliena), i valori annui delle locazioni sono di gran lunga più bassi rispetto a Milano e Roma e oscillano complessivamente tra 1.700 e 580 euro/mq.

L'analisi dei tempi di vacancy nelle stesse città fornisce un quadro differenziato (Fig. 3). I tempi di attesa per la locazione di un immobile possono essere alti e pari a 8-6 mesi anche nelle high street più apprezzate di Milano, probabilmente a causa del numero relativamente ridotto di attività commerciali in grado di sostenere alti costi di localizzazione, ma, a volte, i tempi possono anche essere 


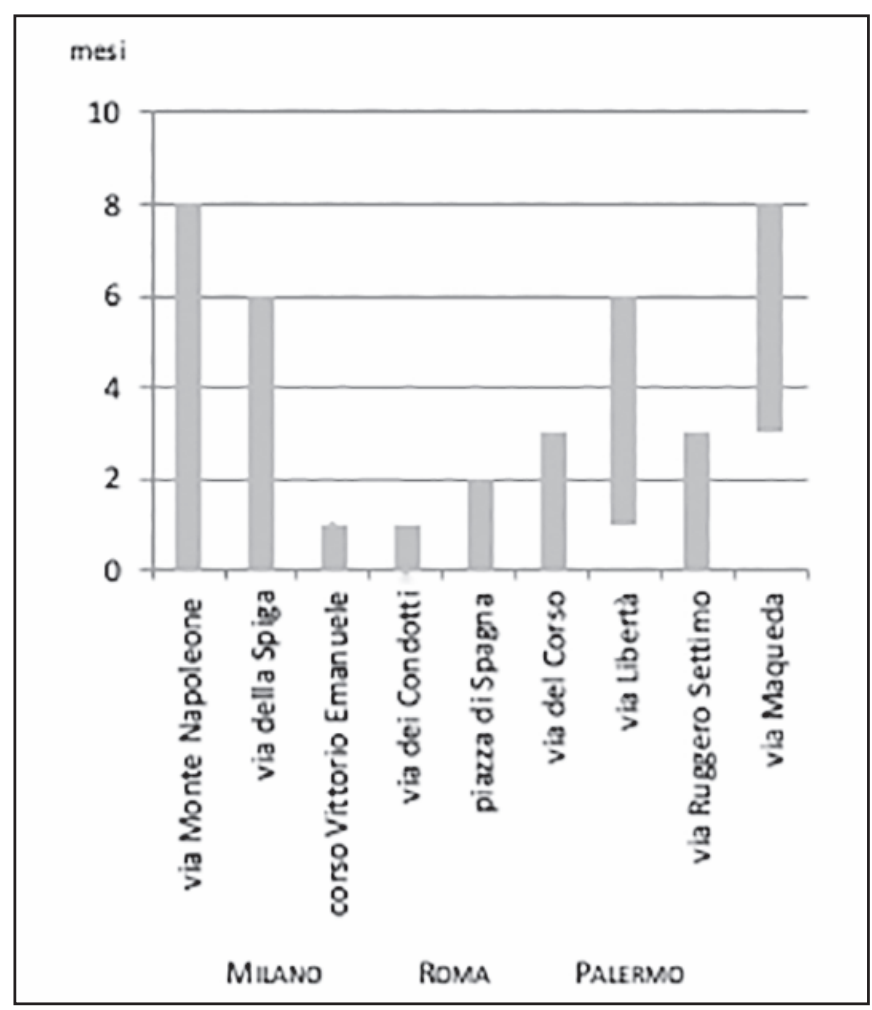

Figura 3 - Tempi di vacancy in alcune high street a Milano, Roma e Palermo (elaborazione su dati 2016, World Capital Real Estate Group).

nulli con la sostituzione del conduttore dell'immobile senza soluzione di continuità temporale.

In modo analogo i tempi di vacancy possono variare da 1 a 6 mesi per gli immobili in via Libertà a Palermo. A parità di tempi massimi di vacancy (8 mesi), tra via Maqueda e via Monte Napoleone ci sono profonde differenze, tra cui l'enorme divario tra le quotazioni che denota la maggiore debolezza della domanda e del tessuto economico e sociale del centro storico di Palermo dove, nonostante la presenza di uno straordinario patrimonio storico e architettonico e della intensa fruizione turistica, le high street hanno risentito negativamente della concorrenza dei tre grandi shopping mall e dell'e-commerce, fattori che hanno contribuito all'innalzamento dei rischi prospettici sul reddito e sul valore del capitale immobiliare commerciale.

\section{IL CASO STUDIO: CITTÀ, IMMIGRATI E RETAIL A PALERMO}

Palermo è una città multiculturale in cui nel 2011, (dati dell'Osservatorio Inter-istituzionale) risiedevano 28.226 stranieri pari al $4,1 \%$ della popolazione totale (696.562). Gli immigrati sono localizzati prevalentemente nei quartieri centrali Tribunali-Castellammare e Palazzo Reale-Monte di Pietà (che formano il Centro Storico), e Politeama, oppure nei quartieri semi-centrali Oreto, Zisa e Noce (Fig. 4).

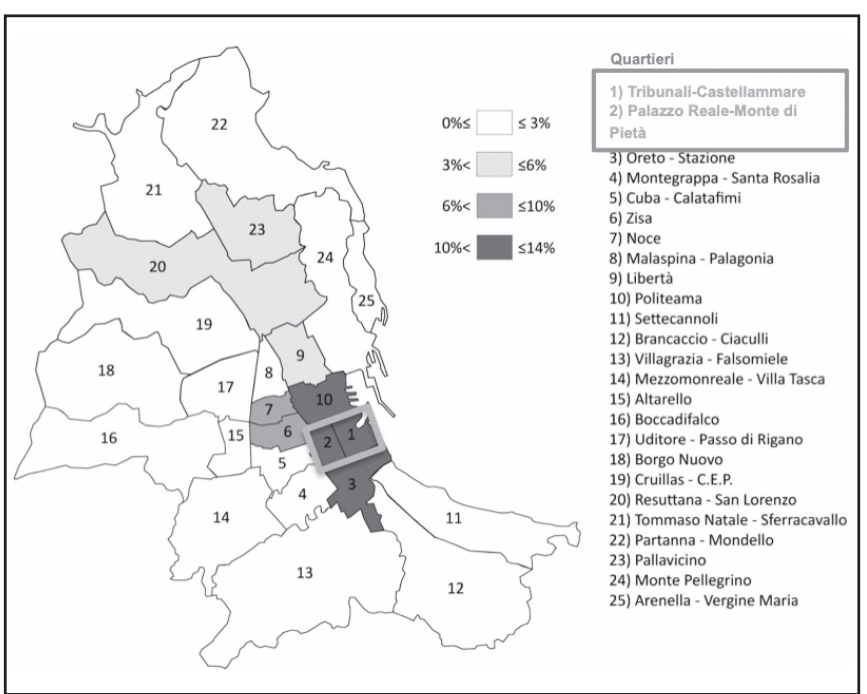

Figura 4 - Localizzazione degli immigrati nei quartieri di Palermo (2011).

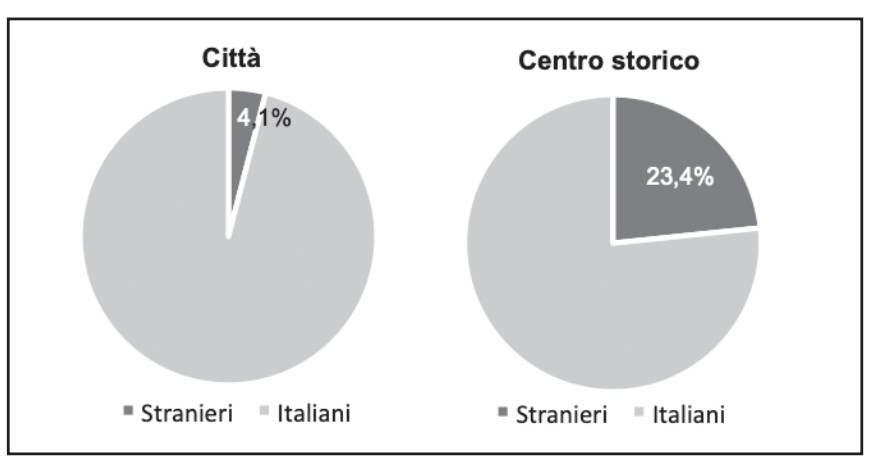

Figura 5 - Incidenza degli stranieri sulla popolazione residente a Palermo e nel Centro Storico (2011).

La concentrazione è particolarmente alta nel Centro Storico dove l'incidenza degli stranieri raggiunge il $23,4 \%$ dei residenti complessivi (6.488) (Fig. 5) e dove sono presenti oltre 80 nazionalità, anche se le comunità più numerose sono quelle provenienti da Bangladesh, Sri Lanka, Cina, Tunisia, Ghana, Mauritius e Romania (Fig. 6).

La scelta delle comunità di immigrati di localizzarsi nel centro storico ha prodotto conseguenze rilevanti sul mercato immobiliare locale.

Una presenza così numerosa implica, innanzitutto, I'utilizzo di una considerevole quota del patrimonio immobiliare residenziale, anche se gli immigrati risiedono prevalentemente in immobili di bassa qualità edilizia o con elevato indice di affollamento in conseguenza del loro reddito-soglia (Napoli et al., 2016b; Napoli, 2017) e sono esposti al rischio di trasferimento quando si attivano processi di gentrification, al pari di quanto accade ad altri gruppi sociali 'indigeni' economicamente deboli.

Anche l'uso degli spazi pubblici subisce modificazioni per effetto delle modalità di interazioni interne ed esterne alle 
La rendita urbana nella città multiculturale: attività commerciali, migranti e declino urbano nel centro storico di Palermo

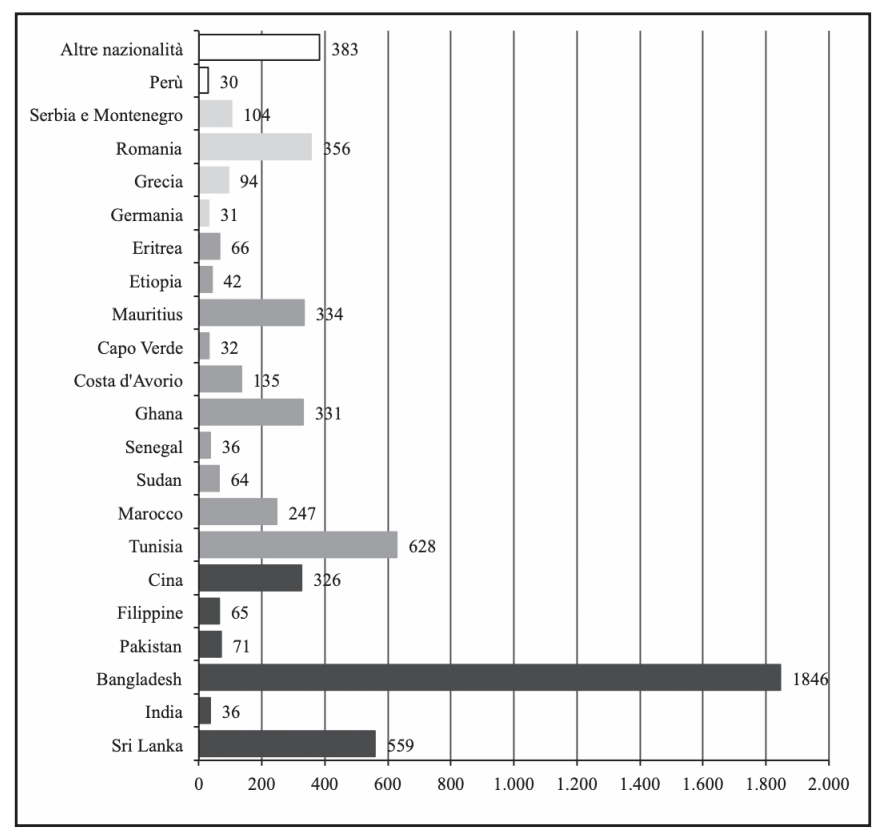

Figura 6 - Numerosità degli immigrati per nazione di provenienza, Centro Storico di Palermo (fonte: Bonafede e Napoli, 2015, su dati 2011).

comunità di stranieri, in termini sia di abitudini e orari di fruizione, sia di tipologia di fruitori, formando nuove gerarchie di spazi inclusivi o esclusivi (Bonafede e Napoli, 2015).

Un'altra conseguenza diretta riguarda I'uso degli immobili a destinazione commerciale, ovvero la gestione di attività di commercio al dettaglio, di negozi di vicinato, o di servizi, che rafforza la presenza degli immigrati e il loro radicamento nel quartiere. Queste attività possono essere rivolte alla fruizione da parte della comunità di appartenenza, dell'intera cittadinanza, oppure dei turisti che visitano il centro storico.

Nella situazione attuale di abbondanza di offerta di locazione di immobili a destinazione commerciale, gli immigrati contribuiscono attivamente alla tenuta del mercato immobiliare locale e assicurano la continuità del reddito fornito ai proprietari degli immobili.

Per verificare il ruolo dei migranti in questo specifico segmento di mercato, è stata condotta un'indagine di rilevazione delle attività economiche che sono localizzate in alcune strade del centro storico a prevalente vocazione commerciale (Fig. 7):

- corso Vittorio Emanuele o Cassaro (al-Qasr), che è stato I'asse portante della città fino al XVI secolo;

- via Maqueda, realizzata tra la fine del 1500 e gli inizi del 1600, incrocia corso Vittorio Emanuele suddividendo la città in quattro Mandamenti. Costituisce la nuova direttrice di espansione della città verso nord, poi prolungata da via Ruggero Settimo e via Libertà;

- via Roma, realizzata nel diciannovesimo secolo come sventramento del tessuto storico, ha sempre avuto una vocazione commerciale (negozi e grandi magazzini) e terziaria (sede di numerosi istituti bancari) che è in crisi da diversi anni;

- via Calderai, storicamente a prevalente localizzazione di attività artigianali (lavorazione di metalli) in parte sostituite da altre attività gestite da migranti;

- via Ponticello, via secondaria di accesso al mercato Ballarò;

- mercato Ballarò, mercato storico all'aperto per la vendita di prodotti agroalimentari;

- via Bara all'Olivella-via dell'Orologio sistema di strade a prevalente localizzazione di attività di ristorazione.

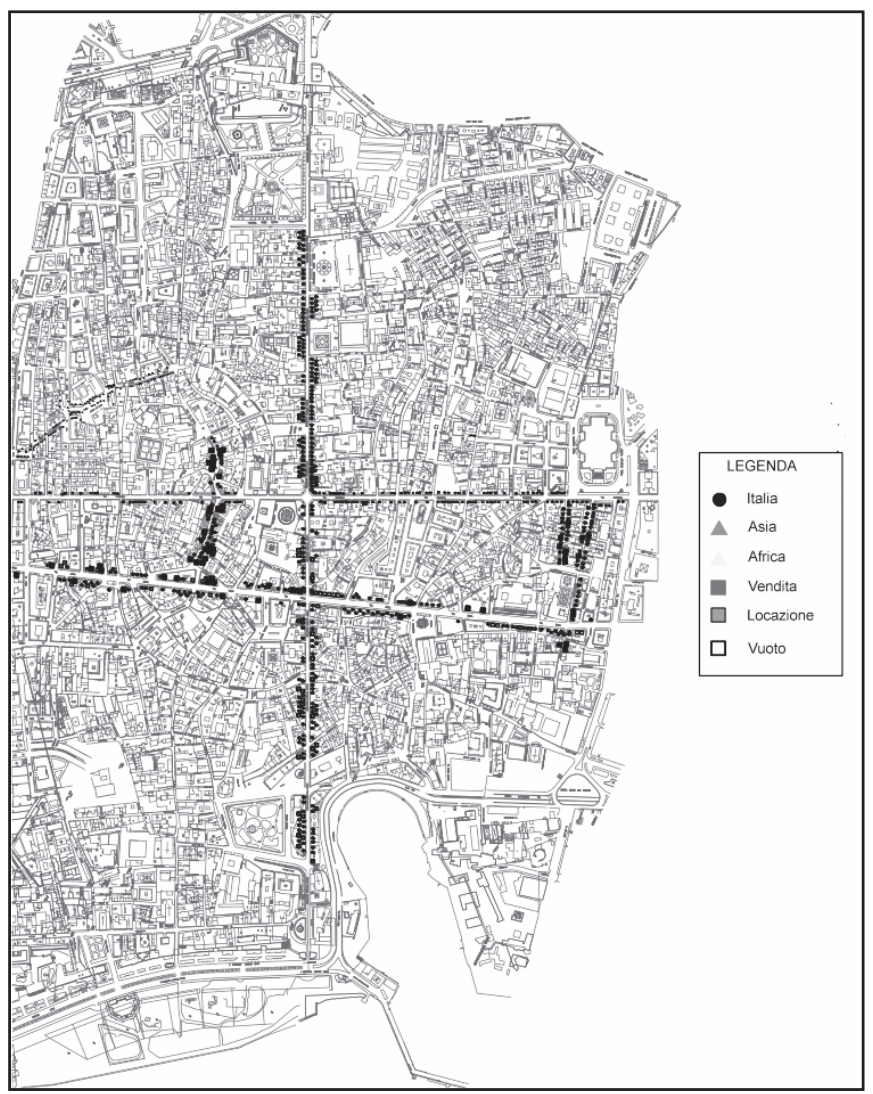

Figura 7 - Ubicazione degli immobili a destinazione commerciale del caso studio (Centro Storico di Palermo).

Sono stati analizzati complessivamente 1.130 immobili, a destinazione commerciale o servizi, dal punto di vista dello stato d'uso (utilizzato/non utilizzato), della tipologia di attività economiche (commercio al dettaglio/ristorazione o vendita di alimentari) e della provenienza geografica dei conduttori (continente).

Un primo dato che emerge (Fig. 8) è la quota di immobili non utilizzati che è superiore a un quinto del totale $(22 \%)$. Questo valore è da considerarsi elevato considerando che si tratta di assi principali del centro storico dove la funzione commerciale è storicamente radicata. La richiesta di immobili come sede di attività di ristorazione (bar, fast- 


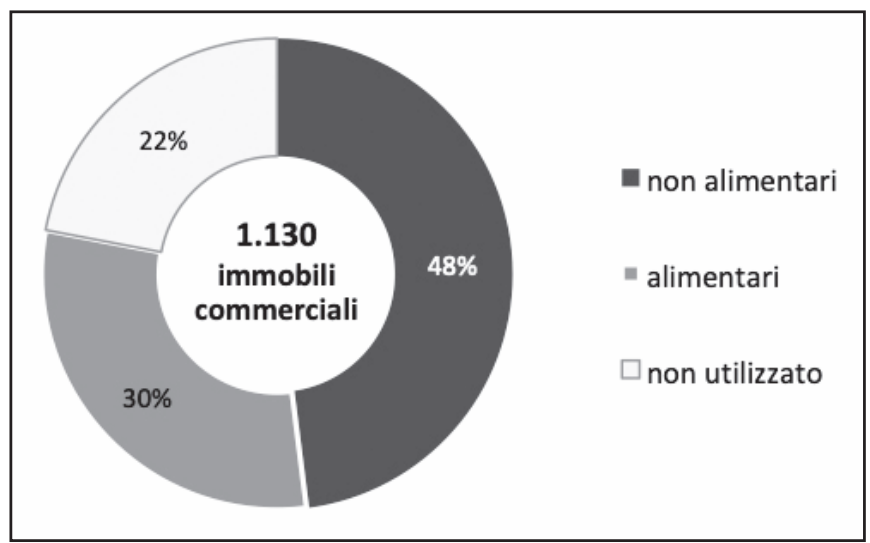

Figura 8 - Stato d'uso degli immobili commerciali del caso studio.

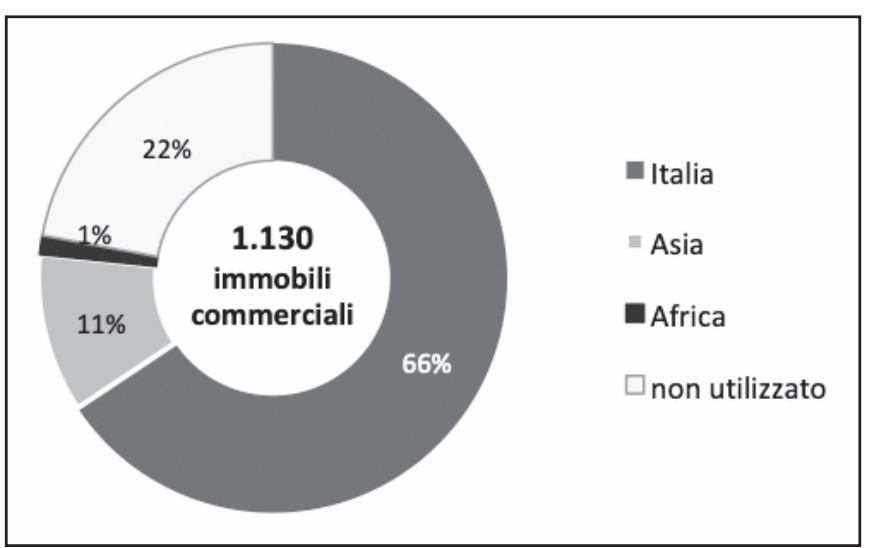

Figura 9 - Origine geografica dei gestori delle attività commerciali nel caso studio.

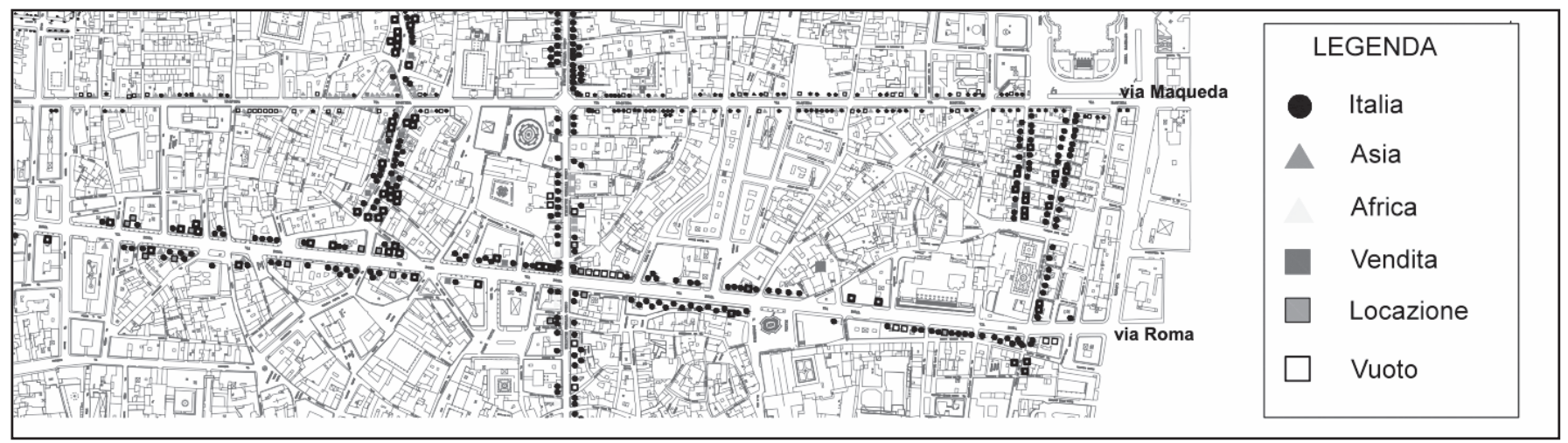

Figura 10 - Ubicazione delle attività commerciali in via Roma e via Maqueda.

food, pub e ristoranti) è pari al 30\%, invece la presenza degli immigranti è pari a $12 \%$ del campione, con una netta prevalenza di asiatici (11\%) e una piccola presenza di africani (1\%) (Fig. 9).

Il confronto dei dati relativi a via Maqueda e via Roma (Figg. 10-11) consente di valutare gli esiti, fino ad oggi opposti,

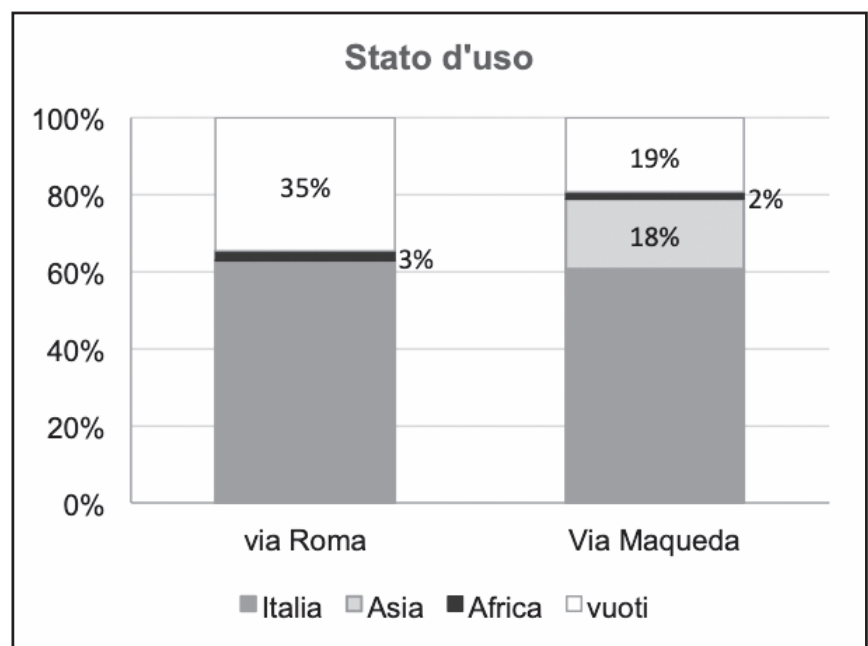

Figura 11 - Origine geografica dei gestori delle attività commerciali in via Roma e via Maqueda. conseguenti ai provvedimenti della Amministrazione Comunale in tema di pedonalizzazione e di istituzione di Zone a Traffico Limitato (ZTL). Anche se entrambe le vie ricadono nel perimetro di una $Z T L$, via Maqueda è stata resa pedonale da piazza Verdi a piazza Vigliena (dove si connette all'area pedonale di corso Vittorio Emanuele); al contrario via Roma è rimasta carrabile. Queste decisioni hanno creato le condizioni per la ripresa della domanda di locazione di nuove attività commerciali nella parte pedonale di via Maqueda, e hanno anche favorito la sostituzione immediata (senza vacancy) di alcune attività in declino con attività di ristorazione. Via Roma invece è rimasta penalizzata in termini di scarsa accessibilità, accentuando il processo, già in atto, di declino come asse commerciale che si traduce in aumento di immobili non utilizzati e in periodi di vacancy superiori a un anno. In via Roma la percentuale di immobili a destinazione commerciale vuoti è alta e pari al 35\%, inoltre gli immobili locati a stranieri sono un numero esiguo. In via Maqueda, al contrario, anche se permane una quota di immobili non utilizzati (19\%), la presenza di stranieri è consistente e pari al $20 \%$, e si registra una netta prevalenza di asiatici (in particolare del Bangladesh) che intercettano una parte delle esigenze di consumo di giovani, turisti e residenti con fastfood etnici e vendita di prodotti alimentari con aperture prolungate in orari notturni. 
La rendita urbana nella città multiculturale: attività commerciali, migranti e declino urbano nel centro storico di Palermo

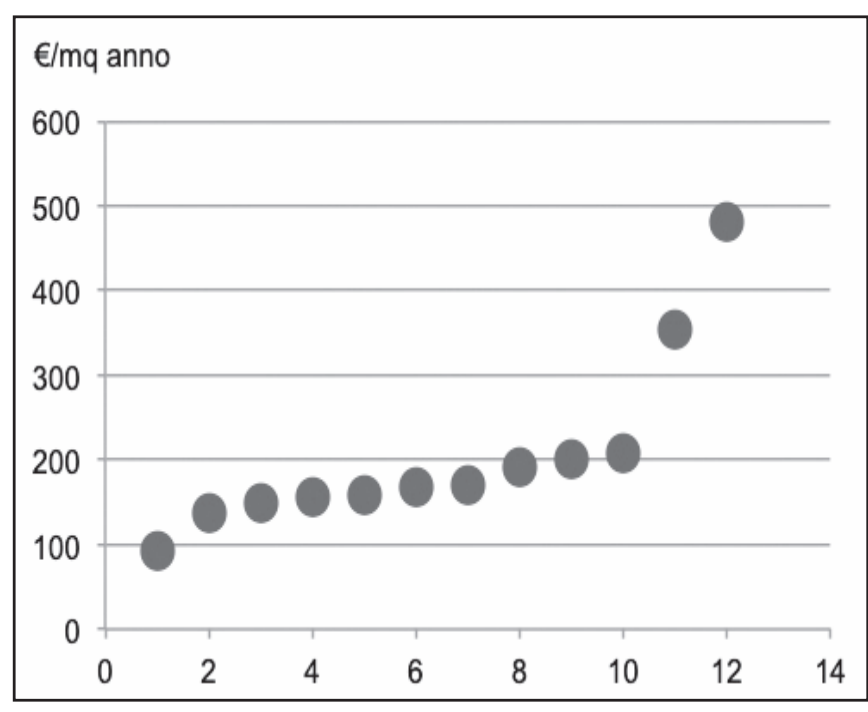

Figura 12 - Canoni di locazione unitari di immobili a destinazione commerciale in via Maqueda (tratto da piazza Vigliena a piazza Giulio Cesare) (rilevazione diretta 2018).

Bisogna però rilevare che gli immobili commerciali locati a immigrati sono localizzati prevalentemente nel tratto di via Maqueda (tra piazza Vigliena e piazza Giulio Cesare) che è rimasto aperto al transito veicolare fino a luglio 2019, dove i canoni di locazione sono bassi e compresi tra 93 e $480 € / \mathrm{mq}$ anno, secondo una rilevazione diretta nel 2018, anche se i valori più frequenti oscillano tra 100 e $200 € / \mathrm{mq}$ annui (Fig. 12). La presenza di attività gestite da immigrati diventa sempre più sporadica man mano che si procede verso il centro della città (piazza Giuseppe Verdi) dove l'incremento dei canoni di locazione costituisce una barriera economica alla loro localizzazione.

\section{CONCLUSIONI}

La modificazione dei modelli localizzativi degli immobili a destinazione commerciale per effetto della diffusione di modalità alternative di vendita al dettaglio (shopping mall, megastore, e-commerce) ha inciso profondamente sulla struttura urbana imponendo la riorganizzazione del mercato immobiliare urbano in termini di rapporti domanda/offerta, valori/redditi e di trasmutazione di liquidità. Anche le zone centrali delle città e le high street stanno subendo fasi di parziale declino con lunghi tempi di vacancy causati dall'eccesso di offerta di immobili in locazione rispetto alla domanda.

Queste trasformazioni, allo stesso tempo, sono state l'occasione per intensificare le interazioni e il radicamento nei quartieri di residenza dei migranti, i quali hanno contribuito a sostenere la domanda di locazione degli immobili (residenziali e commerciali) e ad attenuare la diminuzione delle rendite.

L'analisi del caso studio, formato da alcune high street nel centro storico di Palermo, ha consentito di verificare che la domanda di locazione di immobili commerciali espressa dagli immigrati non è il risultato di una mera sostituzione di conduttori, ma costituisce una quota incrementale della domanda di immobili che altrimenti rimarrebbero non utilizzati, innescando ulteriori minus-valorizzazioni e riducendo sensibilmente la redditività del patrimonio immobiliare.

È importante comunque sottolineare che queste attività, specie quando rivolte all'intera cittadinanza, non sono solo luogo di scambio di merci, o di produzione di profitto e di rendita, ma diventano luoghi di aggregazione e di interazione fondamentali per la costruzione della città multiculturale contemporanea.

\footnotetext{
* Grazia Napoli, Dipartimento di Architettura, Università degli Studi di Palermo e-mail: grazia.napoli@unipa.it

** Giulia Bonafede, Dipartimento di Architettura, Università degli Studi di Palermo e-mail: giulia.bonafede@unipa.it
}

Abbate G., Orlando M., Centri commerciali a Palermo: alla conquista della Conca d'Oro, in Leone M., Lo Piccolo F., Schilleci F. (a cura di), Il paesaggio agricolo della Conca d'Oro di Palermo, Alinea Editrice, Firenze, 2009, pp. 305313.

Appadural A., Modernità in Polvere, Meltemi, Roma, 2001.

ArendT H., The Human Condition, Chicago University Press, Chicago, 1958.

Augé M., Nonluoghi. Introduzione ad una antropologia della surmodernità, Eleuthera, Milano, 2009.

BARONI W., Contro I'intercultura. Retoriche e pornografia dell'incontro, Ombre corte, Verona, 2013.
BAzzı A., La piazza è mia, Rubbettino, Catanzaro, 2012.

Bonafede G., Lo PICCOlO F., Cronache ZEN: la questione abitativa tra assenza di politiche pubbliche, pratiche dal basso ed arte della negoziazione, Archivio di Studi Urbani e Regionali, No. 90, 2007, pp. 47-66.

BONAFEDE G., NAPOLI G., Palermo multiculturale tra rischi di gentrification e crisi del mercato immobiliare nel centro storico, Archivio di Studi Urbani e Regionali, No. 113, 2015, pp. 123-150.

Bonafede G., NAPOLI G., Erraticism and Multicultural Permeability of Urban Fabric in Palermo, in Piccinini L.C., Chang T.F.M., Taverna M., Iseppi L. (eds.), The Erratic Behavior of the Landscape-cultural Mosaic: Emotion, 
Energy, Experience, Proceedings of the 20th IPSAPA/ISPALEM International Scientific Conference, Reggio Calabria (Italy) July 7th-8th, 2016, 2017, pp. 139-150.

BONAFEDE G., SCHILleCI F., "Frantumazione e armonia: dinamiche della "diluizione" urbana nella Piana dei Colli di Palermo", in Leone M., Lo Piccolo F., Schilleci F. (a cura di), Il paesaggio agricolo nella Conca d'Oro di Palermo, Alinea Editrice, Firenze, 2009, pp. 293-304.

Camagni, R., Economia urbana. Principi e modelli teorici, La Nuova Italia Scientifica, Roma, 1992.

CANNAROzzo T., "La governance mafiosa e I'assalto al territorio", in Leone M., Lo Piccolo F., Schilleci F. (a cura di), Il paesaggio agricolo nella Conca d'Oro di Palermo, Alinea, Firenze, 2009.

Ciuna M., Milazzo L., Salvo F., A mass appraisal model based on market segment parameters, Buildings, Vol. 7(34), 2017, pp. 1-13.

Crosta P.L., Società e territorio, al plurale. Lo "spazio pubblico" - quale bene pubblico - come esito eventuale dell'interazione sociale, Foedus, No. 1, 2000, pp. 40-53.

DAMESICK P., E-commerce and UK retail property: Trends and issues, Briefings in Real Estate Finance, Vol. 1, No. 1, 2001, pp. 18-27.

Forte F., Antoniucci V., De PaOla P., Immigration and the Housing Market: the Case of Castelvolturno in Campania Region, Italy, Sustainability, No. 10, issue 343, 2018, pp. 1-17.

GiAmpino A., Picone M., SCHILleCi F., The shopping malls as an emergent public space in Palermo, The journal of Public Space, No. 2, 2017, pp. 85-96.

Giuffrida S., Ventura V., Trovato M.R., Napoli G., Axiology of the historical city and the cap rate. The case of the old town of Ragusa Superiore, Valori e Valutazioni, No. 18, 2017, pp. 41-55.

Holston J., "Spaces of Insurgent Citizenship", in Sandercock L. (ed.), Making the Invisible Visible. A Multicultural Planning History, University of California Press, Berkeley, Los Angeles, 1998.

MAROtTA P., SChILleCi F., "Il controverso ruolo dei centri commerciali per la definizione dello spazio pubblico nella trasformazione della città contemporanea", in Schilleci F., Lo Piccolo F. (a cura di), Forme e processi per il progetto di territori. Pratiche e prospettive nella Sicilia occidentale, FrancoAngeli, Milano, 2016, pp. 106-119.

Moccia F.D., SGobвo A., La polarizzazione metropolitana: I'evoluzione della rete della grande distribuzione verso un sistema policentrico sostenibile, Liguori Editore, Napoli, 2013.

NAPOLI G., "Financial sustainability and morphogenesis of urban transformation project", in Gervasi O., Murgante, B., Misra, S., Gavrilova, M.L. Rocha A.M.A.C., Torre C., Tanjar D., Apduhan B.O. (eds.) ICCSA 2015, Part III, LNCS No. 9157, 2015, pp. 178-193.

NAPOLI G., Housing affordability in metropolitan areas. The Application of a Combination of the Ratio Income and Residual Approaches to Two Case Studies in Sicily, Italy,
Buildings, Vol. 7(4), No. 95, 2017, pp. 1-19.

Napoli G., VAlentı A., Giuffrida S., "The urban landscape and the real estate market. Structure and fragment of the axiological tessitura in a wide urban area of Palermo", in Piccinini L.C., Chang T.F.M., Taverna M., Iseppi L. (eds.), The Turning Point of the Landscape-cultural Mosaic: Renaissance Revelation Resilienc, Proceedings of the 19th IPSAPA/ISPALEM International Scientific Conference, Napoli (Italy) July 2nd-3rd, 2015, 2016a, pp. 67-78.

Napoli G., Giuffrida S., Trovato M.R., "Fair Planning and Affordability Housing in Urban Policy. The Case of Syracuse (Italy)", in Gervasi, O. et al. (eds.), Computational Science and Its Applications, Vol. 9789, 2016b, pp. 46-62.

NAPOl G., Giuffrida S., VAlENTI A., "Forms and functions of the real estate market of Palermo. Science and knowledge in the cluster analysis approach", in Stanghellini S., Morano P., Bottero M., Oppio A. (eds.), Appraisal: from Theory to Practice, Results of SIEV 2015, Springer International Publishing, 2017a, pp. 191-202.

Napoli G., Giuffrida S., Trovato M.R., Valenti A., Cap rate as the interpretative variable of the urban real estate capital asset: A comparison of different sub-market definitions in Palermo, Italy, Buildings, Vol. 7(3), No. 80, 2017b, pp. 1-25.

Rızzo F., II capitale sociale della città, FrancoAngeli, Milano, 2003.

SANDERCOCK L., Toward Cosmopolis. Planning for Multicultural Cities, Wiley, Chichester, 1998.

SANDERCOCK L., When Strangers Become Neighbours: Managing Cities of Difference, Planning Theory and Practice, Vol. 1, No. 1, 2000, pp.13-30.

SASSEN S., Whose Cities Is It? Globalization and the Formation of New Claims, Public Culture, No. 8, 1996, pp. 205-223.

Sassen S., The Global City, New York, London Tokyo, Princeton University Press, Princeton, NJ, 2001.

ScotT A.J. Città e regioni nel nuovo capitalismo. L'economia sociale delle metropoli, II Mulino, Bologna, 2011.

Soja E.W., Beyond Postmetropolis, Urban Geography, Vol. 32, No. 4, 2011, pp.451-46.

Soja E.W., Postmetropolis: Critical studies of Cities and Regions, Blackwell Publishers, Oxford-Malden (MA), 2000.

TODARO V., "Fenomeni di differenziazione sociale", in Vinci I., La Greca P. (a cura di), Sicilia. Rapporto sul territorio 2018, Urbanistica Dossier, No. 16, 2018, pp. 21-25.

Weltevreden J.W.W., Van Rietberger T., E-shopping versus city centre shopping: The role of perceived city centre attractiveness, Economische en Sociale Geografie, Vol. 98, No. 1, 2007, pp. 68-85.

YounG, I. M., Justice and the Politics of Difference. Princeton University Press, Princeton, NJ, 1990. 